University of Rhode Island

DigitalCommons@URI

Open Access Dissertations

1989

\title{
Population Dynamics in Two Nesting Groups of the Leatherback Turtle, Dermochelys Coriacea and Implications for Management
}

M. Tundi Agardy

University of Rhode Island

Follow this and additional works at: https://digitalcommons.uri.edu/oa_diss

\section{Recommended Citation}

Agardy, M. Tundi, "Population Dynamics in Two Nesting Groups of the Leatherback Turtle, Dermochelys Coriacea and Implications for Management" (1989). Open Access Dissertations. Paper 508.

https://digitalcommons.uri.edu/oa_diss/508

This Dissertation is brought to you for free and open access by DigitalCommons@URI. It has been accepted for inclusion in Open Access Dissertations by an authorized administrator of DigitalCommons@URI. For more information, please contact digitalcommons-group@uri.edu. 


\title{
POPULATION DYMAMICS IN TWO MESTING GROUPS OF THE LEATHERBACK TURTLE, DERHOCHELYS CORIACEA, AND IMPLICATIONS FOR MAKAGEMENT
}

\author{
H. TUKDI AGARDY
}
A DISSERTATIOA SUBMITTED IM PARTIAL FULFILLMENT OF THE REQUIREMENTS FOR THE DEGREE OF DOCTOR OF PHILOSOPHY IN THE BIOLOGICAL SCIENCES UKIVERSITY OF RHODE ISLAKD 1989 
DOCTOR OF PHILOSOPHY DISSERTATION

OF

M. TUNDI AGARDY

\section{Approved :}

Dissertation Committee
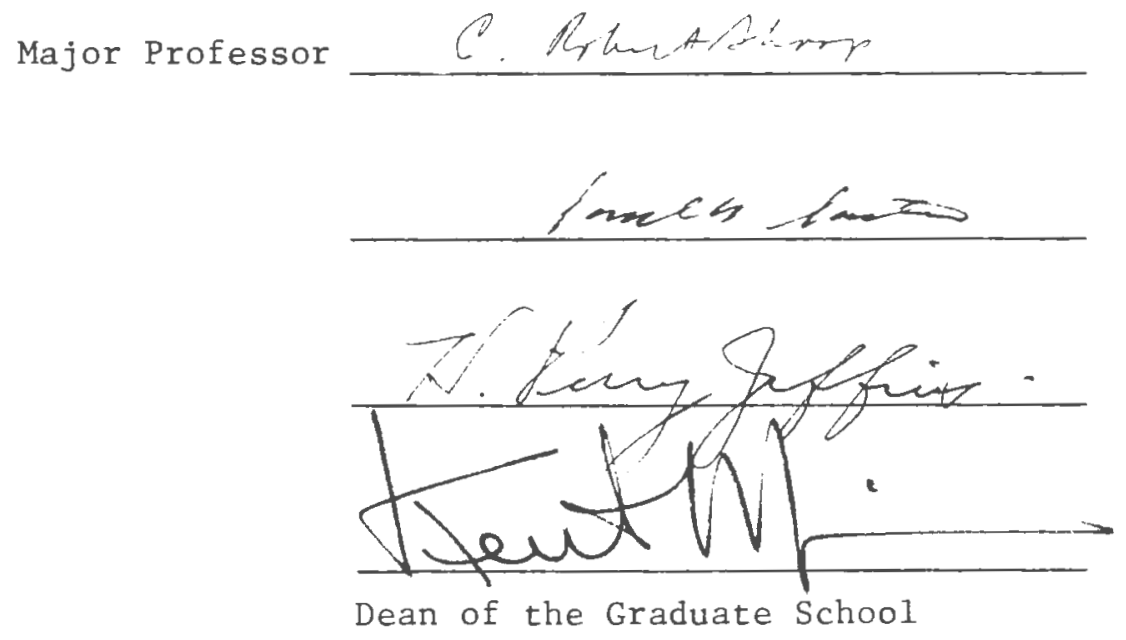

UNIVERSITY OF RHODE ISLAND 


\section{ABSTRACT}

The leatherback sea turtle, Dermochelye coriacea, is a highly migratory and pelagic endangered species. Leatherbacks are globally distributed, with pantropical nesting populations frequenting the Caribbean, Atlantic, Indian and Pacific oceans. These nesting groups appear to have cohesive and predictable occurrence, but the true demic structure of any population subgroup has never been demonstrated. Using tro independent iso-electric focusing methods to analyze blood proteins, this study shoved that the North Atlantic population of leatherback turtles is indeed subdivided into at least tro, though probably many more, genetically distinct stocks.

That the Atlantic population of Dermochelys, previously assumed to be a contiguous, panmictic assemblage, is subdivided has important implications for management. First, since nesting groups appear to exhibit no gene flov, each nesting population needs to be treated as a separate management unit. Second, managers 111 have to look at demes objectively to determine vhere a concentration of effort and funds vill produce the greatest recovery for the species. Lastly, demes vill have to be monitored to determine if they are approaching minimum viable population size and to quantify the level of inbreeding. 
Information on the structure and movement of populations is critical for predictive modeling of population grovth and for attempted management of the species based on such population models. For example, a demographic model such as the Leslie matrix can demonstrate how a defined population will react to decreased mortality in any population sector. The results of theoretical modeling in this study show that for the North Atlantic leatherback turtle, as for the loggerhead (Caretta caretta) population modeled by Crouse et al. (1987), protection of large juveniles is the most critical management action that can be taken. The implications of this finding are of major importance to management, since current conservation measures for this and all other sea turtle species focuses almost exclusively on protection of eggs at the nesting beaches. 


\section{ACKNOWLEDGMENTS}

Like the best major professors, Dr. C. Robert Shoop has provided inspiration, guidance, technical advice, and good friendship throughout the course of this dissertation research and vriting. Unlike many such professors, hovever, he has managed to do so with an unfailing ability to instill his sense of humor and vonderful spirit into the vork, and this has made the process utterly enjoyable. Many heartfelt thanks to you, Dr. Shoop. Special thanks are also due to Dr. Saul Saila, who also provided inspiration and help, with a modicum of patience besides. Dr. Peter August, who planted the seeds for so much of my thinking on these and other subjects, deserves special credit. Thanks also to Suzanne Ayvazian, vho stood at my side at the best and the vorst of times, and made graduate school an experience that I will always remember with fonóness and a smile. 
PREFACE TO THE MANUSCRIPTS

This dissertation follovs manuscript format and is presented as three separate papers. The first paper describes the genetic variability in tro North Atlantic populations of the leatherback turtle as derived from electrophoretic studies, and vas vritten for submission to the herpetological journal Copeia. The second paper is a short description of a blood sampling technique and vill be submitted as a note to Copeia. The third and final paper describes more generally the population dynamics of these tro stocks and the management implications of the genetic and demographic vork, and vas vritten for submission to the journal Conservation Biology or Biological Conservation. 
TABLE OF CONTENTS

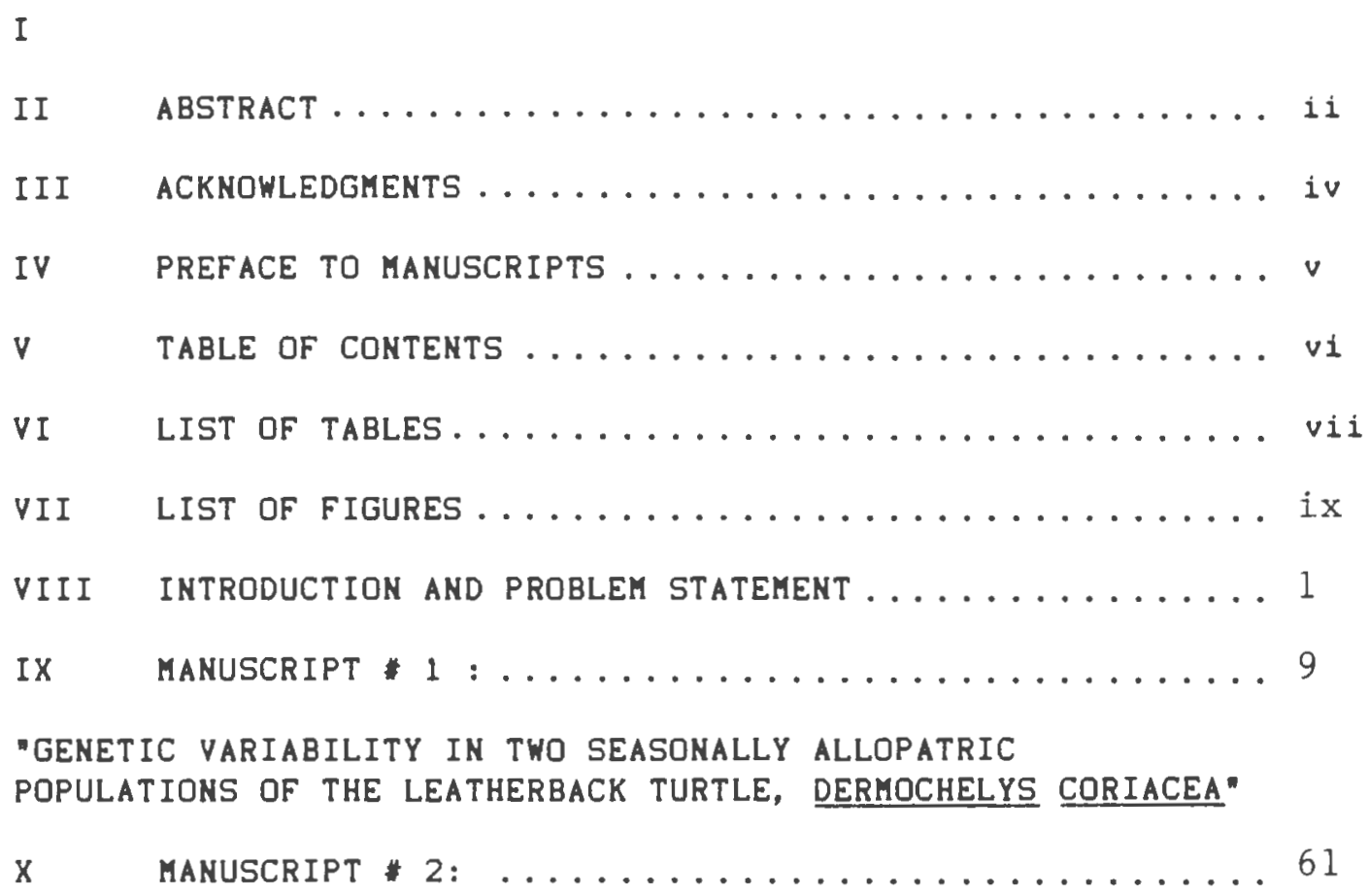

"AN EFFECTIVE METHOd TO OBTAIN BLOOD SAMPLES FROM LARGE
SEA TURTLES"
XI MANUSCRIPT $3: \ldots \ldots \ldots \ldots \ldots \ldots \ldots \ldots \ldots \ldots \ldots$

"WHY INFORMation ON POPULATION DYMAMICS IS CRITICAL TO THE CONSERVATION OF ENDANGERED SPECIES: LESSONS FROM SEA TURTLE RECOVERY EFFORTS"

XII APPENDICES: ...................... 108

A: STAINING REACTIONS FOR IEF GELS FOR MS. 1

B: LESLIE MATRIX SIMULATIONS FOR MS. 3

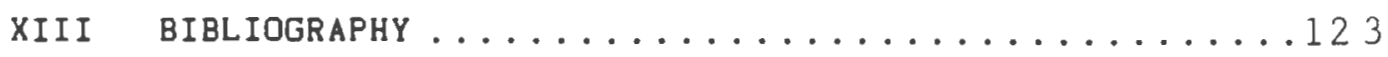




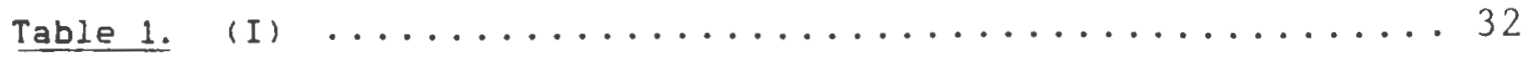

Binary scored data on presence or absence of the most prominent allozyme visible in electrophoretically separated and stained blood samples from trelve, tro, and ten adult leatherback sea turtles from Costa Rica, New England, and the Virgin Islands, respectively.

\section{Table 2. (I)}

Estimated heterozygosity values (\%) in tro nesting populations of D. coriacea as determined by electrophoretic separation of seven polymorphic proteins and specific enzyme staining.

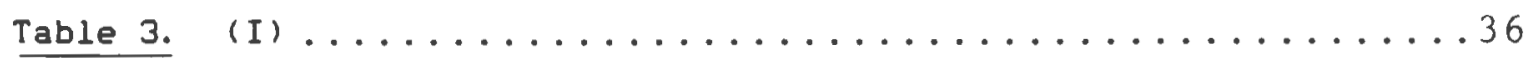

Nearest neighbor (NN) classification (James, 1985) of electrophoretically separated and specifically stained leatherback blood proteins, using binary data from Table 1 vith 22 cases and 7 variables.

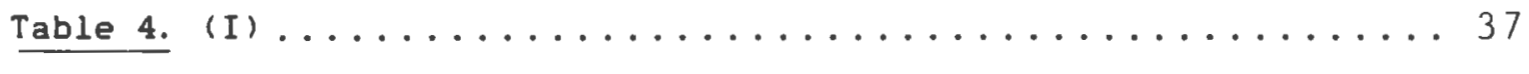

Transformed densitometry data for the 8 most prominent protein variables taken from stained, electrophoretically separated blood proteins of adult females nesting in Costa Rica (samples 1-12) and the Virgin Islands (samples 15-24). Also included are tro samples from two stranded leatherbacks of unknovn origin (samples 13 and 14).

Table 5. (I) $\ldots \ldots \ldots \ldots \ldots \ldots \ldots \ldots \ldots \ldots \ldots \ldots \ldots \ldots \ldots \ldots$

Discriminant functions generated from total protein stained IEF 
gel densitometry data on adult female leatherback turtle blood proteins, using the 3 most discriminatory variables (protein bands $3(a), 5(b)$, and $7(c)$.

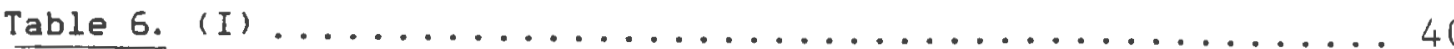

Results of forvard stepwise discriminant analysis of leatherback turtle blood protein data from densitometry readings. The results are presented as number of correctly classified observations in each sampling group.

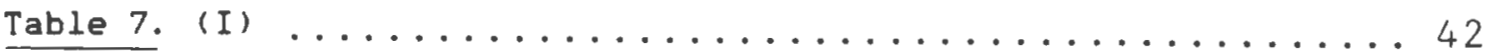

Classification of tro blood samples from stranded adult

leatherback turtles of unknown origin using nearest neighbor

classification algorithm (James, 1985).

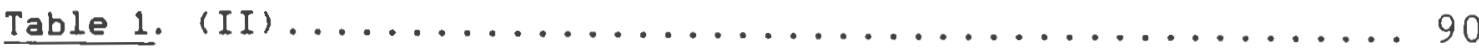

Hypothetical life history parameters for Dermochelys coriacea

used as a basis for Leslie matrix simulations.

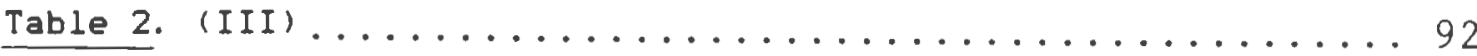

Approximate eigenvalues (lamba estimates) resulting from Leslie

matrix simulations of leatherback turtle population grovth for

various scenarios with different survivorship probabilities for stage classes. 


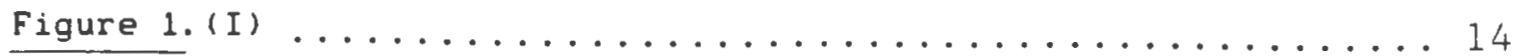
Major nesting beaches used by Dermochelys coriacea in the Caribbean region.

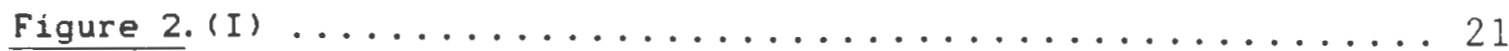

Needle insertion point for blood sampling of adult leatherback turtles.

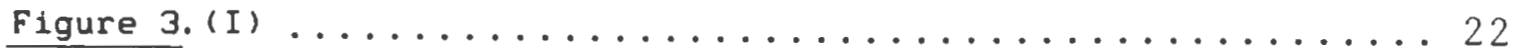

Sampling sites in Costa Rica and the U.S. Virgin Islands.

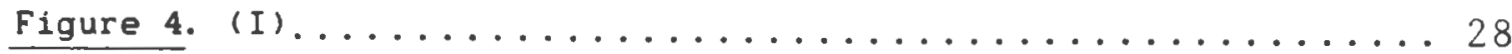

Example of specific enzyme stained isoelectric-focusing (IEF) gel.

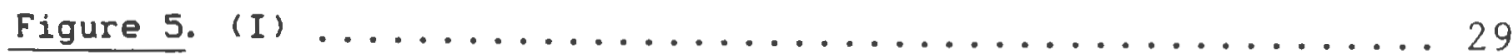

Example of total protein stained isoelectric-focusing (IEF) gel.

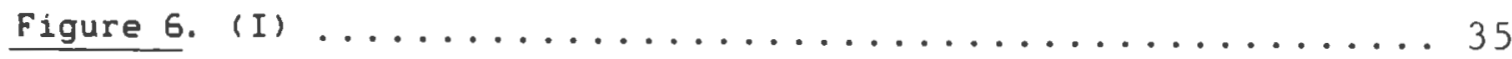

Example of densitometry readings for a blood sample taken from an adult leatherback turtle in Costa Rica, analyzed electrophoretically, and stained for total proteins.

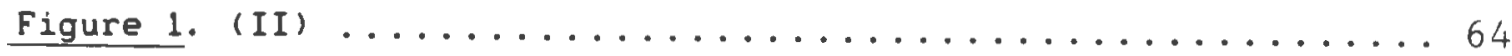
Needle insertion point for blood sampling of adult leatherback turtles.

Figure 1. (III) $\ldots \ldots \ldots \ldots \ldots \ldots \ldots \ldots \ldots \ldots \ldots \ldots \ldots \ldots \ldots \ldots \ldots$ Major nesting beaches used by Dermochelys coriacea in the Caribbean region.

Figure 2. (III)

Hypothesized migration routes of the leatherback in the North 
Atlantic region (after Lazell, 1980)

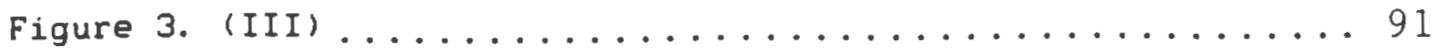

A comparison of simulated population trends, first (A) using hypothetical survivorship estimates given in Table 2; then modified

(B) to increase juvenile survivorship by $10 \%$. and decrease egg survivorship by $25 \%$.

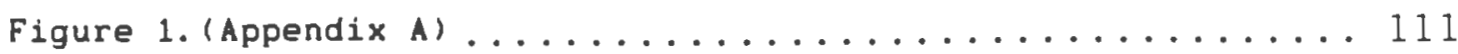
Staining reactions for LDH, PGH, 6-PGD, and PEP

Figure 2. (Appendix A) ..................... 112 Staining reactions for EST, HK, and GAPDH

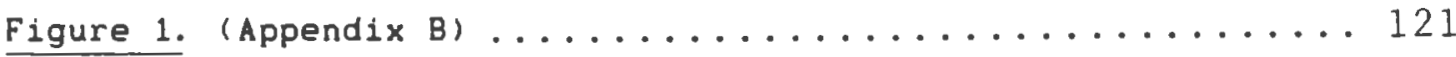
Additional projections from hypothetical Leslie matrix simulations, using various survivorships values 
PROBLEM STATEMENT AND INTRODUCTION

TO DISSERTATION 


\section{POPULATION DYNARICS IN TWO NESTING GROUPS OF THE \\ LEATHERBACK TURTLE, DERMOCHELYS CORIACEA, AND IMPLICATIONS FOR MANAGEMENT}

The leatherback turtle, Dermochelys coriacea, is one of the largest and least studied reptilian species. It shares many ecological characteristics with the other seven species of sea turtles found vorldride, including numerous adaptations for life at sea in which the only normal contact with land is during nesting or at hatching. The land-based activities of sea turtles are relatively vell known, but ve knov little about their lives at sea. The gap in our knovledge includes some very basic life history data such as life span and intrinsic rate of increase in any population, information that is sorely needed for management. Since the leatherback turtle has endangered species status and risks imminent extinction, these basic questions must be ansvered.

Taxonomically, the leatherback is the monotypic member of the family Dermochelyidae, while the other seven living sea turtle species are in the family Cheloniidae. Significant differences betveen the leatherback and the other species include large adult size and an ability to regulate body temperature (Greer et al., 1973). Dermochelys coriacea adults undergo large-scale migrations vith home ranges that commonly exceed 5000 kilometers (Pritchard, 1976; Lazell, 1980). To vithstand the severe environmental conditions of migrations from tropical breeding sites to temperate and sub-arctic feeding grounds and diving to great depths, 
leatherbacks have evolved a semi-homeothermic capability. Individuals are able to maintain body temperatures up to $18^{\circ} \mathrm{C}$ above the ambient vater (Standora et al., 1984) with an efficient countercurrent heat exchanger in the circulatory system (Friar et al., 1972).

Dermochelys has such unusual anatomical features that some systematists argue for a taxonomic separation at the subordinal level from the other sea turtles (Smith and Smith, 1979). The most obvious morphological characteristic unique to leatherbacks is the seemingly "soft" shell. The carapace, although present, is reduced to a relatively thin mosaic-like shell under the tough but flexible skin. This adaptation may have evolved in response to two ecological features: (1) the enormous size of adults, sometimes exceeding 900 kllograms (Eckert and Luginbuhl, 1988), which may discourage the predation that rould make a shell necessary, and (2) deep diving behavior, exceeding 470 meters (Eckert et al., 1986), possibly enhanced by tissues which can tolerate compression under great pressures. Indeed, Rhodin (1985) has shorn that leatherback bone is different from that of other reptiles, being much more flexible and compressible than the bone of other sea turtles.

Dsteological studies of leatherbacks have also led to some surprising and counter-intuitive theories about their rate of grovth. The large size and high fecundity of Dermochelyg may suggest a demographic pattern of slow maturation and long life span that characterize many other chelonid species. Hovever, Rhodin (1985) postulated that leatherbacks grow very rapidly, attaining 
reproductive maturity in two to three years. If Rhodin's estimate is correct, it has serious implications for projections of population growth and, correspondingly, for management. How such a rapid grovth rate, an over 60,000 -fold increase in veight in only 730 days, could be sustained by an animal adapted to a diet of soft-bodied coelenterates comprised mostly of vater, is unknown. The metabolic requirements of such rapid grovth are probably such that hatchling and juvenile leatherbacks vould have to eat foods vith fairly high protein content (Bels et al., 1989). Despite the fact that other sea turtle species are opportunistic feeders when young (Carr, 1987). they exhibit much slover grovth than postulated for leatherbacks by Rhodin.

Knovledge of individual grovth rate and population replacement rate are required before recovery of this endangered species can be comprehensively undertaken. Even vithout concrete information about these parameters, assumptions about grovth rate, fecundity, and survivorship can be used to formulate theoretical models of population dynamics that can be verified or disproved through the accumulation of survivorship data. Hovever, such models are not realistic if the population to be modelled has not been clearly defined.

I argue that the critical information necessary to promote the recovery of this species is the definition of the population to be recovered. Leather-backs are not equally endangered throughout the vorld, as some "populations" (e.g. the French Guiana nesting group) are quite large and apparently suffer little human-induced mortality. Thus, how leatherbacks are organized into demes (which correspond to 
management units) and which demes are in gravest danger of extinction is of critical importance.

Administrators or natural resource managers responsible for the recovery of leatherback populations ought to be concerned with the efficiency of their efforts, given that time and funds are limited. Ideally, the scientific program should aim to provide the folloring: 1. Identification of the management unit. This identification must be comprehensive to include all age classes and both sexes vithin the deme.

2. Determination of population sizes and trends for each management unit. Tagging studies, growth curve generation, and other research should aim to establish the population replacement rate ( $R$ ). 3. Identification of the most sensitive stocks and demographic groups to target for management. Since resources for conservation are limited, the most effective and fastest results will come from this sort of allocation.

The manuscripts included in this dissertation describe techniques and results that elucidate stock structure, genetic heterozygosity, and theoretical population dynamics in Atlantic leatherback turtles and discuss wh such demographic information is crucial for efficient and timely managenent. So little is known about the biology of the leatherback that every bit of information gained is potentially important to conservation. Oving to logistical considerations, researchers have spent an inordinate proportion of time studying a very narrow aspect of this species' ecology, namely nesting. Much more vork is needed on stock delineation, population 
dynamics, movement patterns, and resource requirements at sea, to further elaborate the demography of this enigmatic endangered species. 


\section{LITERATURE CITED}

Bels, V., F. Rimblot-Baly and J. Lescure. 1989. Croissance et maintien en captivite de la Tortue Luth, Dermochely coriacea (Vandelli, 1761). Revue fr. Aquariol. 15 (2): 59-64.

Carr, A.F. 1987. Impact of nondegradable marine debris on the ecology and survival outlook of sea turtles. Mar. Poll. Bull. 18(6): 352-356

Eckert, K. A. and C. Luginbuhl. 1988. Death of a giant. Marine Turtle Nevsletter 43: 2-3.

Eckert, S.A., D.W. Nellis, K. A. Eckert, and G. L. Kooyman. 1986. Diving patterns of tro leatherback turtles (Dermochelys coriacea) during internesting intervals at Sandy Point, St. Croix, U.S. Virgin Islands. Herpetologica 42(3): 381-388.

Frazier, J. 1987. Semantica and the leathery turtle, Dermochelys coriacea. J. Herp. $21(3): 240-242$

Greer, A., J.A. Lazell, and R. Wright. 1973. Anatomical evidence for a countercurrent heat exchanger in the leatherback turtle (Dermochelys coriacea). Nature 244: 181.

Lazell, J.D. 1980. New England vaters: critical habitat for marine turtles. Copeia $1980(2): 290-295$.

Pritchard, P.C.H. 1976. Post-nesting movements of marine turtles (Cheloniidae and Dermochelyidae) tagged in the Guianas. Copeia $1976(4): 749-754$ 
Rhodin, A.G. 1985. Comparative chondro-osseus development and grovth of marine turtles. Copeia 1985 (4): 752-771.

Smith, H.K. and R.B. Smith. 1979. Synopsis of the Herpetofauna of Mexico. Volume VI. John Johnson: North Burlington, Vt. 1044 pp.

Standora, E.A., J.R. Spotila, J.A. Keinath, and C.R. Shoop. 1984. Body temperatures, diving cycles, and movement of a subadult leatherback turtle, Dermochelys coriacea. Herpetologica 40: 169-176. 
MANUSCRIPT * 1 :

GENETIC VARIABILITY IN TWO SEASONALLY ALLOPATRIC POPULATIONS

OF THE LEATHERBACK TURTLE, DERMOCHELYS CORIACEA 


\section{GENETIC VARIABILITY IN TWO SEASOMALLY ALLOPATRIC POPULATIONS}

OF THE LEATHERBACK SEA TURTLE, DERMOCHELYS CORIACEA

\section{ABSTRACT}

Tro-dimensional polyacrylamide gel electrophoresis vas used to analyze blood samples from adult female leatherback sea turtles (Dermochelys coriacea) to elucidate the stock structure and genetic composition of two North Atlantic nesting populations. The isozyme analyses vere used to estimate both overall levels of heterozygosity in the North Atlantic population and extent to vhich the two sampled populations could be identified as genetically distinct. Blood samples vere collected from nesting female leatherback turtles in St. Croix, U.S. Virgin Islands, and Parismina, Costa Rica, two videly separated sites representing extremes of the Caribbean nesting range for D. coriacea. Isoelectric focusing vas utilized in both specific isozyme identification and total protein densitometry analysis to determine whether the two populations sampled represented two true demes.

Both the non-parametric tests performed on the binary data, indicating presence or absence of a particular allozyme, and multivariate discriminant analyses of the total protein densitometry data established a clear genetic separation of the stocks. In addition, the genetic baseline information shoved how animals stranded or trapped in temperate areas, whose stock identities could not be othervise determined, could be matched to the most probable nesting population of origin, using a maximum likelihood estimator 
and a nearest neighbor classification. Electrophoretic analysis of blood proteins vas thus used in two independent ways to elaborate not only stock structure and demic integrity, but also as a tool for determining the stock affinity of untagged individuals found far from their nesting grounds. 


\section{INTRODUCTIOK}

The leatherback turtle (Dermochelys coriacea), one of five sea turtle species found in the northern Atlantic and one of eight species in existence, is both federally and internationally listed as endangered (Groombridge, 1982). As such, its population numbers are considered lov enough for the species to in danger of extinction (Meylan et al., 1985; Ross 1982), and in some areas, high levels of egg harvesting and habitat lose preclude any immediate hope of recovery (Bustard, 1972). The entire vorldvide population of mature females, the only segment of the population easily censused because only breeding females come ashore and because they appear at the same place in regular intervals, has been roughly estimated at only 115, 000 individuals (Pritchard, 1982).

The leatherback is the largest of the sea turtles and the largest of extant marine reptiles, comonly exceeding $600 \mathrm{kilograms}$ in veight (Mrosovsky, 1987). A recent stranding of an adult turtle In Wales, Great Britain, veighed a record 916 kilograms (Eckert and Luginbuhl, 1988). The leatherback 18 the most videly distributed marine reptile, with individual home ranges exceeding 5000 kilometers (Pritchard, 1976). It thus frequents both troplcal areas and temperate to sub-arctic areas (Brongersma, 1972; Shoop et al., 1981). Despite its large size and impressive movements, the life history and behavioral ecology of Dermochelye remain poorly understood. The highly migratory behavior and pelagic habits of the leatherback have contributed to the lack of information about the species. In 
addition, Dermochelys is sensitive to disturbance, elusive to observe, and with one documented exception (Bels et al., 1989) virtually impossible to raise in captivity (P. Lutz, pers. comm.). These factors, coupled with the relative rarity of the animal, explain some of the paucity of existing biological data.

Our knowledge of the leatherback sea turtle is least solid in those aspects where information is most needed. While certain aspects of the reproductive biology of the circumtropical leatherback nesting populations have been vell documented as annual female fecundity and egg to hatchling survivorship (e.g. Bacon et al., 1984; Balasingham, 1967, Carr and Ogren, 1959; Eckert et al.,1985; Fretey, 1980; Limpus and McLachlan, 1984; Meylan et al., 1985; Pritchard, 1971, 1976; Ros8, 1982 and Schulz, 1982), virtually nothing is known about the population dynamics and ecology of the ocean inhabiting segments of the vorldride population. One important and as yet unanswered question concerns whether male leatherbacks undergo the extensive seasonal migrations that lead breeding females from temperate feeding grounds to tropical nesting areas. Since the movements of males have not been fully documented and since positive evidence of mating in the proximity of nesting beaches is lacking (Eckert and Eckert, 1988), whether geographically separated nesting groups represent genetically distinct demes is not known.

Leatherbacks inhabiting the North Atlantic Ocean utilize tropical nesting beaches throughout eastern Central America, the Antilles, and the northern shores of the South American continent (Figure 1). The largest concentrations of nesting leatherbacks in 


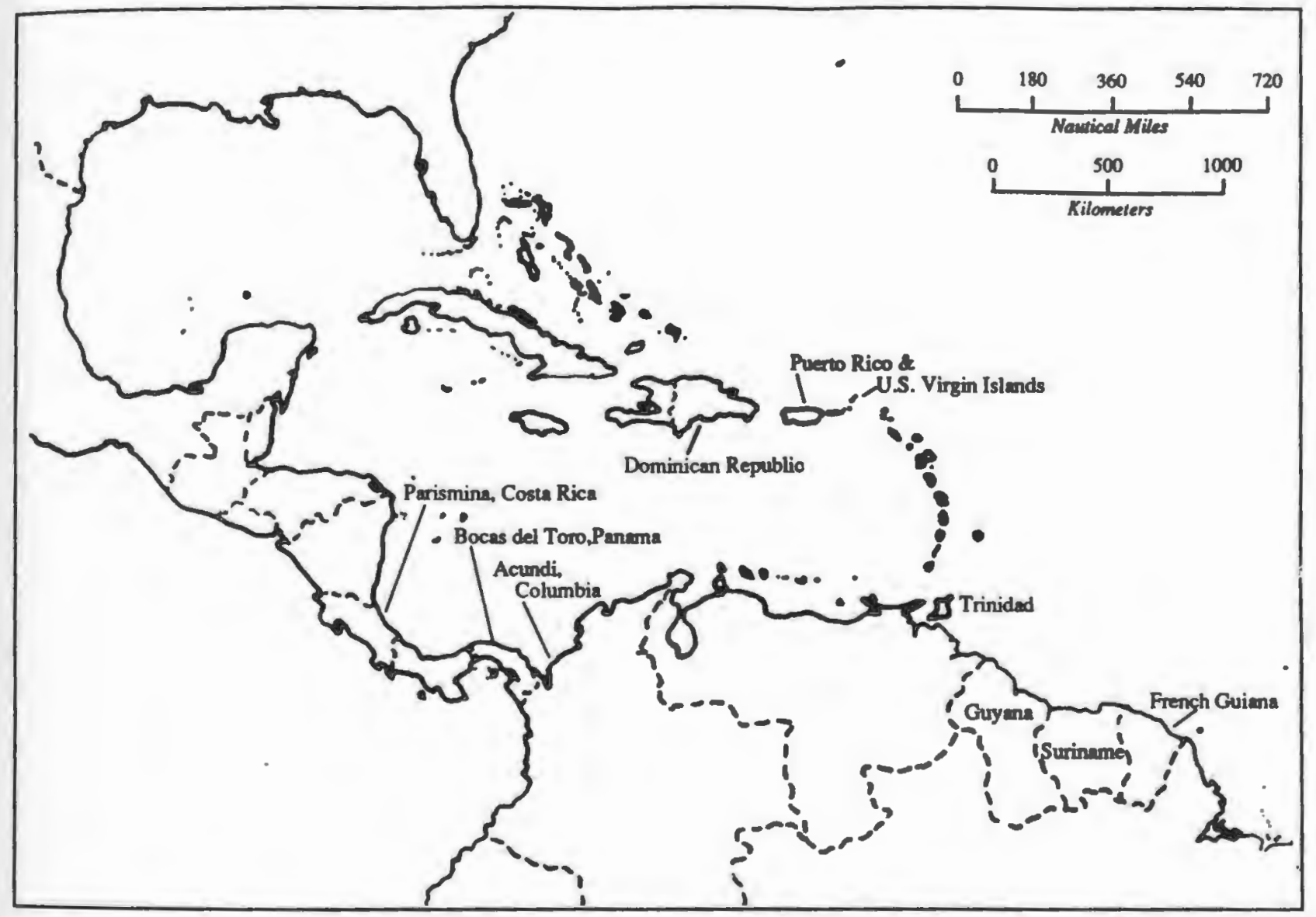

Figure 1. Major nesting beaches used by Dermochelye coriacea in
the Caribbean reglon. 
this region occur in Costa Rica, French Guiana, and Guyana (Pritchard, 1976), although smaller populations return seasonally to use beaches in other parts of the Caribbean such as Puerto Rico, the U.S. Virgin Islands, and Dominican Republic (Meylan et al., 1985). The latter habitats are increasingly under risk from encroachment by beachfront resort developments, so the survival of these already small populations groups may be particularly threatened (Baker, $1980)$.

Questions concerning stock structure and population dynamics of Dermochelys previously have been ignored or ansvered in general and hypothetical terms (Brongersma, 1972; Carr, 1952;), save the recent hypothesis on Virgin Island stock structure that emerged from data on epifaunal encrustation patterns evident on nesting females (Eckert and Eckert, 1988).

The Atlantic leatherback turtle population, for instance, vas assumed to constitute a largely panmictic assemblage, vith open gene flow among nesting groups (Laze11, 1980). The lack of evidence of mating near nesting habitats seemed to point to some central breeding area avay from the nesting beaches (J. Lazell, pers. comm.), perhaps in the temperate or subarctic feeding grounds. In this hypothesized scenario, leatherbacks inhabiting the Atlantic Ocean vould be considered as constituting a single population, with only seasonal population subdivision occurring when the breeding females move to their widely separated nesting beaches to deposit eggs.

The question of stock cohesion and degree of gene flov between and within regional sub-groups of the leatherback population is important for management of the species. Reduced genetic variability 
may hinder the species' ability to adapt to rapidly changing environments (Levins, 1968). The tentative link betreen low levels of heterozygosity and reduced fitness has been argued for many species of vertebrates (see review by Allendorf and Leary, 1986), although the mechanisms depressing fitness are rarely elucidated. Hovever, restricted population size and genetic exchange with other demes may lead to inbreeding and a corresponding increase in expression of deleterious mutations, as has been shovn in studies of the immune repsonses of endangered populations of cheetahs (O'Brien et al., 1986). Inbred vertebrates may have lovered resistance to stressful conditions (Parsons, 1971), and can exhibit significant behavioral changes that are considered "abnormal" (Lynch, 1971). Professional breeders of rare species have long recognized the deleterious nature of reduced genetic variability and actively promote increased heterozygosity via outcrossing (Kleiman, 1980). Frankel and Soule (1981) stated that inbreeding always reduces fitness in animals, and claimed that a 10\% increase in the coefficient of inbreeding vill be expected to produce a 5-10\% decline in reproduction.

Despite some controversy about wat levels of heterozygosity are acceptable in managed populations (see Templeton, 1986 for an extended discussion), genetic analysis remains a necessary prerequisite to endangered species management. This point has been eloquently stated in the case of endangered fish management (Meffe, 1986), but has yet to be established as critical in the management of other marine vertebrates, although marine mammalogists are now 
beginning to look at the problem (P. Tyack, pers. comm.). An analysis of genetic variability exhibited by North Atlantic leatherback populations is used here as a tool to define stock structure and the corresponding units of management, to elucidate breeding behavioral patterns, and to focus questions concerning leatherback biology.

That stock identification is important for sea turtle management cannot be overstated. Not only is it important to identify unit stocks, defined by some level of geographical separation in time and/or space that occur vith some corollary biological discreteness, it is also important to determine vhat factors contribute to stock delineation. Description of these features of managed populations is important in understanding the true limits of population interactions. Clearly, any management measure instituted to protect or rehabilitate a population vill have drastically different effects if applied to small segments of a population, as opposed to the comprehensive population as a wole (Brovn et al., 1987).

Electrophoretic techniques remain one of the most valuable tools for detecting intraspecific differences between members of a population (Hart1, 1980), and are in many vays more cost-effective than higher resolution technqiues such as DNA sequencing and mitochondrial DNA analysis. Morphometric and meristic data are important parameters for detecting such differences, but these characters are more frequently influenced by external factors and may thus distort true unit stock delineations (Sa1la, 1987). Furthermore, comparisons betreen quantitative genetic and morphometric data may be invalid due to uneven statistical 
assumptions (Levontin, 1983). Hovever, a combination of genetic data inferred from electrophoretic analysis and direct observation (for example as provided by tagging studies) can provide highly rigorous estimates of demic structure (Ihssen et al., 1981).

Fisheries biologists have generated huge amounts of quantitative data from biochemical samples to delimit population structure in previously uncharacterized fish stocks. For instance, stocks of highly migratory fish such as salmon, herring, and halibut have been extensively defined using electrophoretic methods (Utter et al.,1987; Grant and Utter, 1984; and Grant et al., 1984). With respect to similarly highly migratory sea turtles, some attempt has been made to quantify genetic variability in loggerhead and green sea turtles (Caretta caretta, Chelonia mydas, respectively) using starch gel electrophoresis (Smith et al., 1977), but as the authors vere interested primarily in the average rate of genetic heterozygosity, genetic delineation of demes vas not attempted. Boven et al. (1989) examined the mitochondrial DNA (mtDNA) of nesting female green turtles and found genetic cohesiveness of nesting populations, hovever since mtDNA is maternal in origin these results do not describe the genetic composition of the population as a whole. My study is the first to describe the population genetic structure and degree of inbreeding exhibited by leatherback turtle populations. It targets two geographically distinct groups of nesting female turtles found at the longitudinal extremes of the vider Caribbean nesting region. Blood samples taken at each site are compared using several different methods of biochemical and 
statistical analyses; the results are used to give credence to the hypothesis that the Atlantic population of Dermochelys coriacea is not a panictic assemblage with open gene flow among nesting groups but is instead divided into independent demes. 


\section{MATERIALS AND METHODS}

Blood samples vere collected from adult female leatherback turtles during their noctural emergences on the beach. To minimize disturbance to the nesting sea turtles, blood samples vere collected immediately after the females finished egg-laying and before the active phase of nest covering began. During this time the animals are relatively still and seem less responsive to external stimuli. Blood vas drawn using a $5 \mathrm{~cm}$ 13-gauge spinal tap needle inserted into the paravertebral sinus of the neck (Agardy, 1989). This technique is generally reliable and minimizes trauma to the animal. For the technique to be successful the needle must be inserted close to the vertebral column (Figure 2) and kept vertical during insertion and blood withdrawl. Because of the extremely viscous nature of Dermochelys blood, both the needle and internal syringe barrel vere coated in heparin, and collected samples vere immediately placed in vacutainers containing EDTA as an anticoagulant. Blood samples vere placed on ice following collection and vere frozen at $-5^{\circ} \mathrm{C}$ vithin $3-4$ hours after collection.

Sampling at the beaches near Parismina, Costa Rica, took place during the period from 10-20 April 1986 and at Sandy Point, St. Croix, U.S. Virgin Islands, from 28 April to 7 May 1986 (Figure 3), under U.S. Endangered Species Permit * 703758 and CITES Permit 698138. These two sites vere selected because they represent geographical extremes of Dermochelys nesting in the Caribbean area, and because research expeditions to these locations vere logistically convenient. The number of adult leatherback turtles using these 


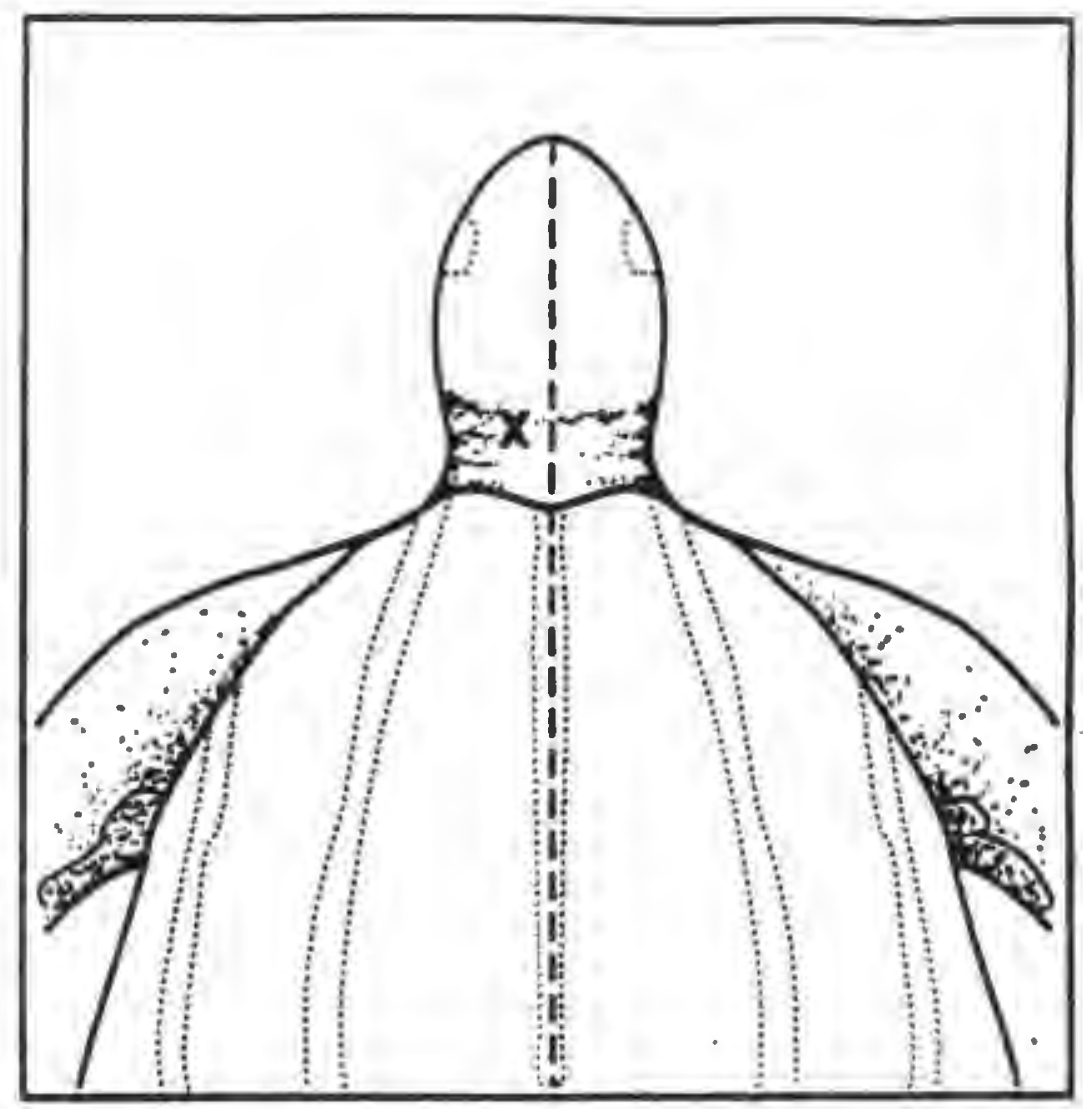

Figure 2. Needle insertion point for blood sampling in adult leatherback turtles. 


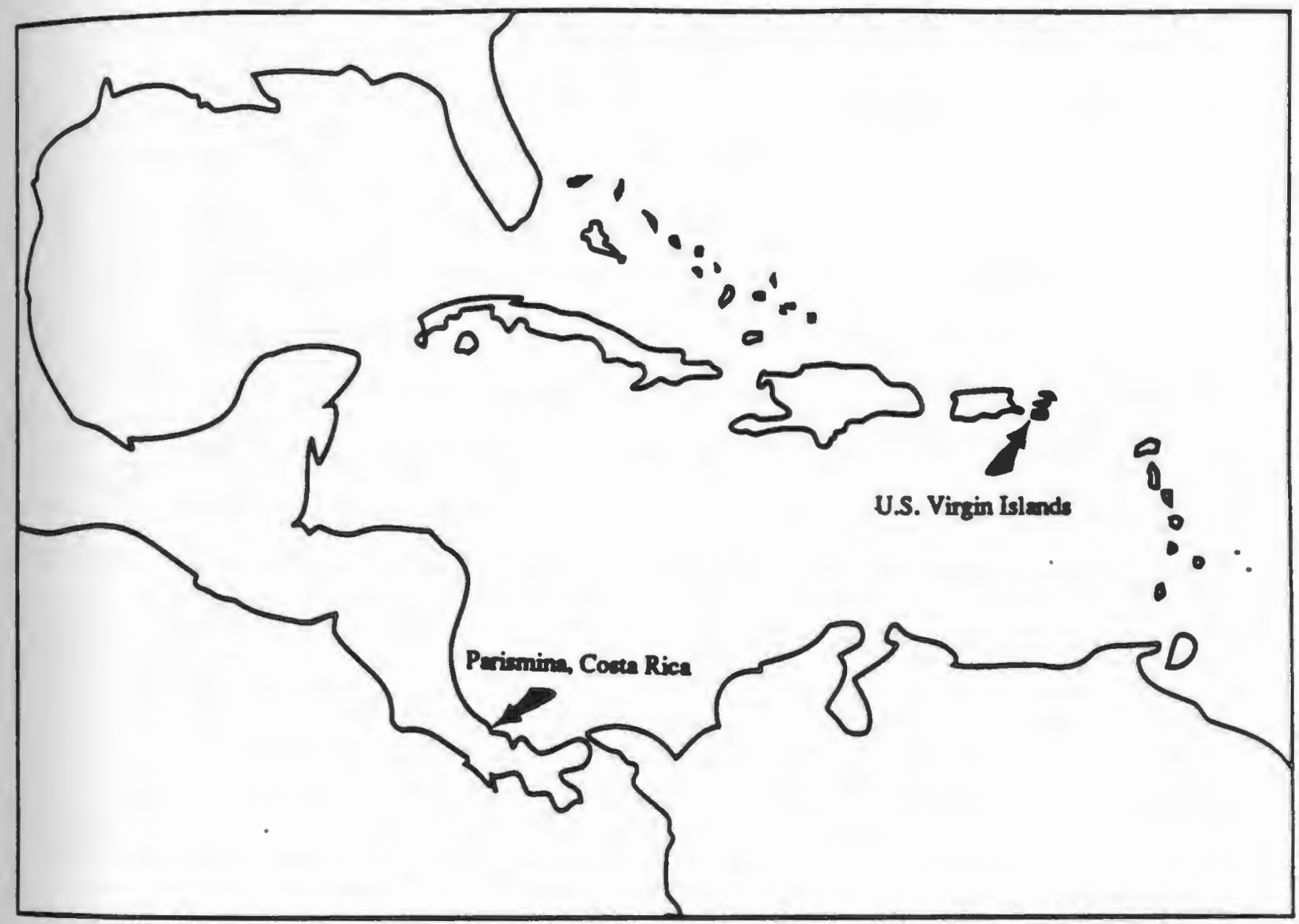

Figure 3. Sampling sites in Costa Rica and the U.S. Virgin Islands. 
beaches during the peak of nesting lapproximately 200 on the beach in immediate proximity to Parismina (Hirth and Ogren, 1987) and 30 on the Sandy Point beach (Agardy, 1981) ensured that the small sample sizes needed for the analysis could be obtained in a short period. The sampling dates were planned in close proximity to decrease the probability of sampling the same female in two different locations. In fact, samples from the Virgin Islands group were taken from tagged and thus individually identified animals, so duplication could not have occurred.

Fifteen blood samples were collected at Parismina and twelve at Sandy Point, from twelve individual female turtles at each locality. When possible, $8-10 \mathrm{ml}$ of blood vere collected, however $2-3 \mathrm{ml}$ proved sufficient for electrophoretic separation and staining. Frozen blood samples were shipped to the University of Rhode Island for storage and analyses.

Several blood samples were collected from stranded leatherback turtle adults in Rhode Island and Massachussetts. Only two of these samples vere fresh enough to be usable: one $5 \mathrm{ml}$ sample obtained from a live female captured in a pound net off Newport on 5 August 1986, the other obtained by Dr. Gregory Early of the New England Aquarium from a dead female adult found on Horseneck Beach, Massachussetts, in July 1986. The samples from the stranded individuals vere frozen and stored with the other samples until analysis.

The entire collection of samples from Costa Rica and the Virgin Islands may have been subjected to a partial thaw in November 1986 when the electrical power at the Department of Zoology, University of 
Rhode Island, was lost for a 36 -hour period. Work done by the National Marine Fisheries Service (S. Gallovay, pers. comm.) had suggested that the most stable of sea turtle blood proteins can resist denaturing, even after successive freeze/thav episodes, although inherently unstable proteins may be prone to configurational change and thus operational dysfunction. Indeed, subsequent IEF analyses and staining of the samples shoved that the relevant proteins had not denatured, since the reactions vent to completion (see Appendix A for enzymatic reactions). These reactions, utilizing an electron transfer method to produce stains on specific IEF bands, require that the targeted enzyme be intact and fully functional for staining to be visible.

Prior to electrophoretic analysis, the blood vas thaved at room temperature and centrifuged at approximately $5000 \mathrm{rpm}$ for 20 minutes. The supernatants vere then diluted with distilled vater to a $1: 1$ concentration. The prepared samples vere micropipetted in 15 ul quantities onto LKB brand paper vicks, which vere then applied to polyacrylamide electrophoretic gels for separation.

The blood proteins were analyzed using an iso-electric focusing apparatus (MRS-150 Electrofocusing tank and E-C-500 constant pover supply coupled with a VWR constant temperature refridgerated bath). All the samples vere run together on polyacrylamide gels, thereby eliminating possible variability in running conditions between samples. Premade polyacrylamide gels (PAG plates) vith a pH range of 3.5-9.5 (LKB Manufacturers) vere used throughout the study. Each of the ten gels containing 26 sea turtle blood samples was run for 2.5 hours at a maximum voltage of 1.5 kilovolts, a maximum 
pover of 25 vatts, and a maximum current of 70 milliamps. A fresh sample of human blood was run in Lane 1 of each gel because the separation of proteins was more clearly visible in an unfrozen sample and running time could be more accurately gauged using the same human blood as a reference point each time.

Specific enzyme staining complexes vere used to detect the presence of allozymes produced at distinct alleles. The specific stains vere of two general classes: chemical detection stains, which employ chemical reagents to produce colored compounds at the sites of enzyme activity, and electron transfer dyes reduced by electron donors to produce a stain. The enzyme complexes assayed included lactose dehydrogenase (LDH), hexokinase (HK), peptidases B and D (PEP), glyceraldehyde-phosphate dehygrogenase (GAPDH), phosphoglucomutase (PGH), phosphogluconate dehygrogenase (PGD), and esterases (EST). In addition, detection of red cell acid phosphatase was attempted without success. Specific staining reactions are diagrammed in Appendix A.

The protocol for detecting these enzymes ras devised specifically for Caretta caretta and Chelonia mydas sea turtle blood by S. Galloray and T. Inabnett (pers. comm.) of the Charleston Laboratory of the Mational Marine Fisheries Service and vere generously provided by them for this study. Running times vere extended by 10-20 minutes per assay and other slight modifications in

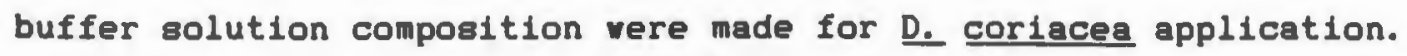
Since these protocols have not yet been published, the buffer and stain recipes are noted briefly below : 
$\underline{\mathrm{LDH}}$ : Incubate gel at $37^{\circ} \mathrm{C}$ for $30-45$ minutes in $.6 \mathrm{~g}$ lactic acid, .04g B-NAD, and $50 \mathrm{ml} .05 \mathrm{M}$ tris/glycine at $\mathrm{pH}$ 8.4. Pour off buffer and add to it .02 g NBT and .005 g PMS, pour over gel and soak until purple bands are visible.

HK : Mix .05 g MTT and .01 g PMS into the folloving buffer: $3 \mathrm{ml} .1 \mathrm{M}$ tris/HCL at pH7.5, $.18 \mathrm{~g}$ glucose B-D+, .04 g ATP (disodium salt), $0.16 \mathrm{~g} \mathrm{NADP,} 80 \mu \mathrm{H}$ G-6-PDH, and .0041 g MgCl $6 \mathrm{H}_{2} \mathrm{O}$. (This is a dark reaction, therefore stains should be added to the buffer in darkness). Pipet this solution onto the gel and roll with a glass rod, then incubate at $37^{\circ} \mathrm{C}$ in complete darkness for 4 hours.

PEP : Pipette and roll onto the gel the folloving: $2 \mathrm{ml} .02 \mathrm{M}$ NaPO at $\mathrm{pH} 7.5, .04 \mathrm{~g}$ peptide, $.02 \mathrm{~g}$ peroxidase, . $5 \mathrm{ml} .1 \mathrm{M} \mathrm{MnCl,} 200$ $\mu 1$ L-amino acid oxidase, and .028 g 3-amino-9-ethyl carbazole. Incubate at $37^{\circ} \mathrm{C}$ for 2.5 hours.

GAPDH : Incubate gel at $37 \circ \mathrm{C}$ in $50 \mathrm{ml} .05 \mathrm{M} \mathrm{tris/HCl}$ at $\mathrm{pH} 7.5$, 40 ul D-glyceraldehyde-3-phosphate (free acid), .06 g NAD, .05 g arsenic acid, .05 g pyruvic acid, .0075 g MTT and .0025 g PMS for 1 hour.

PGM : Incubate gel in .48 g glucose-1-phosphate, .08 g MgCl, $.008 \mathrm{~g}$ NADP, .028 $\mathrm{ml}$ G6PDH $(140 \mu / \mathrm{ml})$, and $50 \mathrm{ml} .5 \mathrm{M} \mathrm{tris/HCl}$ at $\mathrm{pH}$ 7.1 for one hour. Pour off and add .02 g NBT and .004 g PMS.

PGD : Mix $50 \mathrm{ml} .5 \mathrm{Mtris/HCl}$ at $\mathrm{pH} 8.0, .1 \mathrm{~g}$ 6-phosphogloconate (disodium), $2.5 \mathrm{ml} .2 \mathrm{M} \mathrm{MgCl} \mathrm{M}_{2}$ and $50 \mathrm{mg} \mathrm{NADP.} \mathrm{Add} \mathrm{.075} \mathrm{g} \mathrm{MTT}$ and $.015 \mathrm{~g}$ PMS; incubate gel at $37^{\circ} \mathrm{C}$ for tro hours.

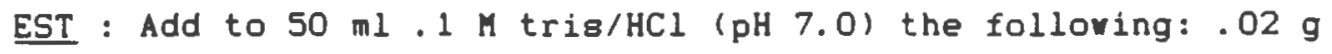
$\propto$-naphthyl acetate, .02 g $\beta$-naphthyl acetate, $.02 \mathrm{~g} \alpha$-naphthyl propionate, 432 ul $\propto$-naphthyl butyrate mixed with acetone. Add 
$.02 \mathrm{~g} \alpha$-naphthyl phosphate, then $.07 \mathrm{~g}$ Fast Blue BB. Incubate, without shaking or bumping staining tray, for 30 minutes.

Each stained gel was scored for presence or absence of allelic products and was then preserved and photographed (Figure 4). The binary data, indicating the presence of proteins coded by each hypothesized locus, were used to measure overall genetic variability in the populations sampled as vell as intra-nesting group differences. A preliminary chi-square analysis was performed on the pooled binary values for each nesting group to determine the extent to which data differed from the null hypothesis expectation that the tro populations would exhibit similar values for genetically-encoded allozyme composition. A non-parametric analysis of the binary data was then used to determine the extent to which samples could be classified into either of the two nesting populations. This analysis, using a nearest neighbor classification technique described by James (1985), assigns each sample to a group based on a type of reverse histogram method. The BASIC computer program outlined by James (1985) was also used to assign unknown samples to either of the two groups. Using another technique, the mean allozyme pattern of each population was also used as the basis for maximum likelihood estimation (MLE) and assignement of unknown samples (Millar, 1987). In addition to the tro specific enzyme detection methods indicated above, two additional gels were treated with a general protein stain employing Coomassie Brilliant Blue R-250 (Fabrizio, $1986)$ to detect all proteins contained in the samples. The additional gels (Figure 5) were then scanned with an EC-910 


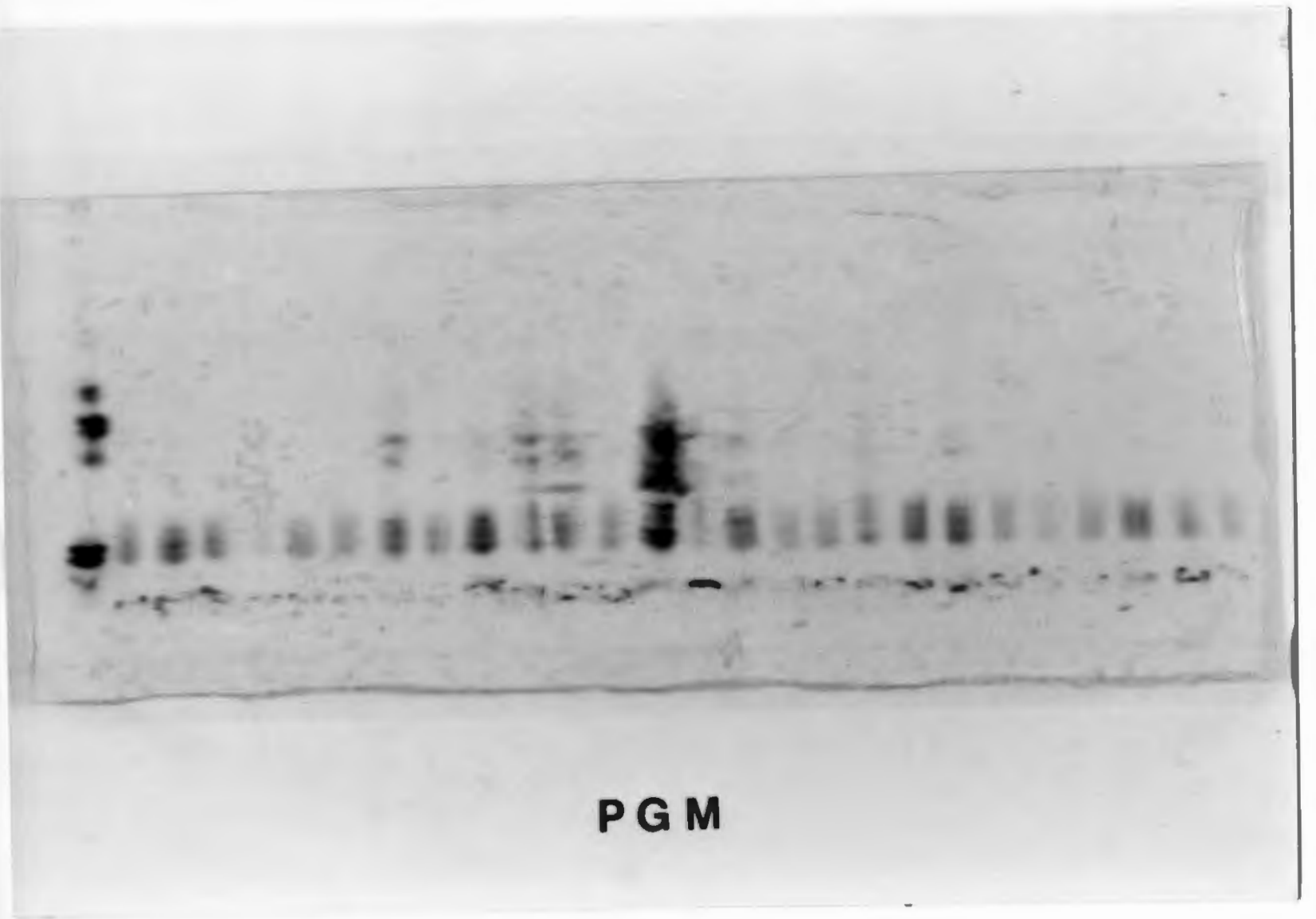

Figure 4. Example of specific enzyme stained isoelectric-focusing (IEF) gel. 


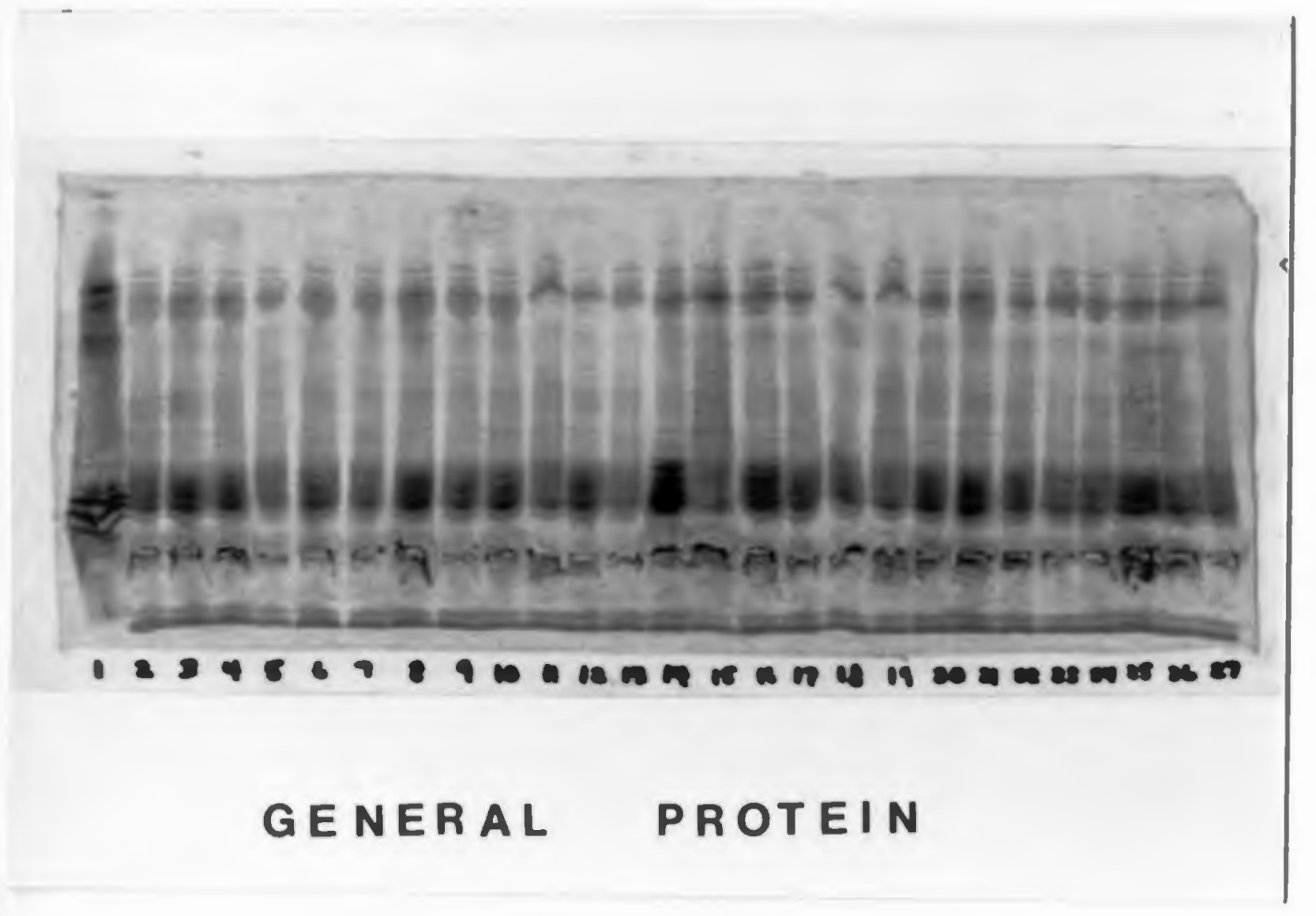

Figure 5. Example of total protein stained isoelectric-focusing (IEF) gel. 
integrated transmission densitometer. From the 30 to 34 proteins detected by this method, eight reference measurements of the most prominent peaks vere chosen for comparison. The concentrations of these eight proteins, given as a proportion of the total integrated area of the protein profile, vere then used to perform a standard discriminate analysis (Fabrizio, 1986 ).

The data obtained from the densitometer readings vere first calculated as percentage of total area, and the fractions vere arcsine transformed to mathematically accentuate the existing differences between values (Snedecor and Cochran, 1980). The transformed values for the eight selected proteins in the Virgin Islands and Costa Rica nesting population samples vere then used in a stepwise disciminate analysis, which indicates discreteness of the two groups and also highlights those measurements most useful in discriminating between groups. 


\section{RESULTS}

Samples were scored according to presence or absence of each of the seven most prominent metabolic allozymes commonly detected through electron transfer dye staining methods. This scoring was binary, the value one representing presence of the common allozyme and zero representing 1 ts absence (Table 1). These data vere used to estimate overall levels of genetic heterozygosity in samples of the North Atlantic leatherback turtle population and to delineate stocks according to genetic differences.

All seven consistently detectable metabolic enzymes investigated: hexokinase (HK), lactate dehygrogenase (LDH), 6phosphogluconate dehydrogenase (PGD), peptide (PEP), esterase a (EST), phosphoglucomutase (PGM), and glyceraldehyde phosphate dehydrogenase (GAPDH), vere polymorphic in Dermochelys coriacea. Average heterozygosity across all seven enzyme systems of all samples $(K=24)$ was 0.33 (Table 2). Although both Costa Rica and Virgin Islands subgroups had similar levels of heterozygosity, the samples from each population were heterozygous at different loci.

A chi-square analysis vas performed on the binary data by pooling the samples in each subgroup and comparing mean values of the number of times the common allozyme for each enzymne system vas present. This group-group comparison shoved a clear distinction between stocks. The null hypothesis, that the seven polymorphic proteins occur independently of the population subgroup, vas rejected at the $95 \%$ confidence level $\left(x^{2} .05,6=15.32>12.59\right)$. 
Table 1. Binary scored data on presence or absence of the most prominent allozymes ( 0 =absence : 1 =presence) in seven enzyme systems: lactate dehydrogenase (LDH), phosphoglucomutase (PGM), 6-phosphogluconate dehydrogenase (PGD), peptide (PEP), esterase A (EST), hexokinase (HK), and glyceraldehyde phosphate dehydrogenase (GAPDH) from electrophoretically separated and stained blood samples taken from adult leatherback turtles in three locations.

Sample * LD

(sampling

locations)

(Costa Rica)

$\begin{array}{llll}1 & 0 & 0 & 0 \\ 2 & 0 & 0 & 0 \\ 3 & 0 & 0 & 1 \\ 4 & 0 & 0 & 1 \\ 5 & 0 & 0 & 1 \\ 6 & 0 & 0 & 0 \\ 7 & 0 & 1 & 1 \\ 8 & 1 & 0 & 1 \\ 9 & 0 & 0 & 0 \\ 10 & 0 & 1 & 0 \\ 11 & 0 & 1 & 0 \\ 12 & 0 & 1 & 0\end{array}$

PGD

PEP

EST

HK

GAPDH

12

0

1

1

0

0

0

0

1

1

1

1

0

0
1

1
1

1

0

1

14

0

1

(Virgin Islands)

$\begin{array}{ll}15 & 0 \\ 16 & 0 \\ 17 & 1 \\ 18 & 1 \\ 19 & 1 \\ 20 & 0 \\ 21 & 1 \\ 22 & 1 \\ 23 & 0 \\ 24 & 0\end{array}$

$\begin{array}{lll}0 & 0 & 0 \\ 0 & 1 & 1 \\ 1 & 0 & 1 \\ 1 & 0 & 0 \\ 1 & 0 & 0 \\ 0 & 0 & 0 \\ 1 & 0 & 1 \\ 1 & 0 & 1 \\ 0 & 0 & 1 \\ 0 & 0 & 1\end{array}$

$\begin{array}{lll}1 & 0 & 1 \\ 1 & 0 & 0 \\ 0 & 0 & 0 \\ 0 & 0 & 1 \\ 0 & 0 & 1 \\ 0 & 0 & 1 \\ 1 & 0 & 1 \\ 0 & 0 & 0 \\ 0 & 0 & 0 \\ 1 & 1 & 0 \\ 0 & 0 & 0 \\ 0 & 0 & 0\end{array}$

\section{Unknowns (Nev England)}


Table 2. Estimated heterozygosity values ( $\%$ in tro nesting populations of Dermochelys coriacea as determined by electrophoretic separation of seven polymorphic proteins and specific staining. For full names of proteins see Table 1 .

Loc1 Represented

LDH PGD PEP EST PGM HK GAPDH

Location

COSTA RICA

$(N=12)$

$\begin{array}{llllllll}.08 & .42 & .50 & .33 & .33 & .08 & .33 & .30\end{array}$

U.S.V.I.

$(N=10)$

$\begin{array}{llllllll}.50 & .58 & 0 & .50 & .08 & .25 & .08 & .08\end{array}$


Because of small sample size and no assumption of a normal distribution of the binary values, a non-parametric nearest neighbor classification was used to arrange samples into the demic groups based on allozyme patterns. The test assigned samples into the tro groups with a Bayes error of $22.73 \%$ (Table 3 ). The Bayes error value suggests the maximum rate of misclassification using these parameters for discrimination 18 less than one in four.

The total protein densitometry analysis, in which the entire complement of proteins present in the sample vere stained and readby densitometer, resulted in protein profiles having 28 to 48 detectable peaks (Figure 5). Some of these peaks vere artifacts caused by unusually wide or heterogeneous IEF bands. Of the 28 consistently apparent peaks, eight of the most prominent vere selected as representative bands for analysis to make the data set manageable (Figure 6). The eight variables, representing the integrated areas of the largest peaks, vere then arc-sin transformed (Table 4) and vere used in a stepvise linear disciminant analysis (Saila and Martin, 1987). This analysis, like the nearest neighbor classification, assigns samples to groups according to the eight variables; results shoved a clear genetic separation of stocks.

The total protein densitometry data vere assumed to have a normal distribution for the mutlivariate discriminant analysis. Thus, in creating the group one and group two covariance matrices, the computer analysis treated them as statistically identical. Using cross-validation, the program chose only the most highly discriminatory variables and then performed the grouping using this function. 


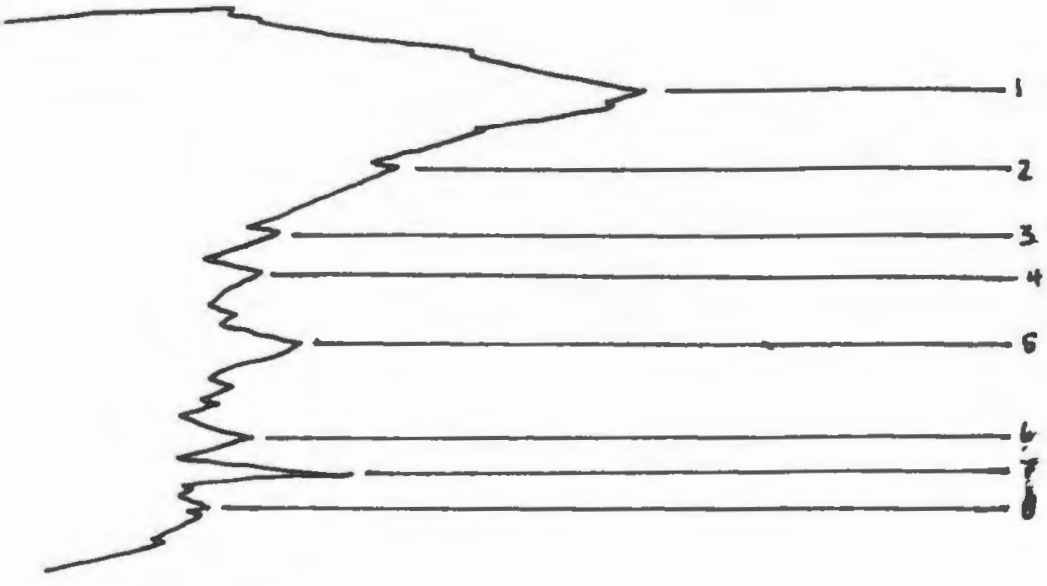

Figure 6. Example of densitometry readings for a blood sample taken from an adult leatherback turtle in Costa Rica. 
Table 3. Nearest neighbor (NN) classifcation (James, 1985) of electrophoretically separated and specifically stained leatherback blood proteins, using binary data from Table 1 vith 22 cases using 7 variables. Asterisks denote misclassified cases.

Group I: Costa Rica Samples

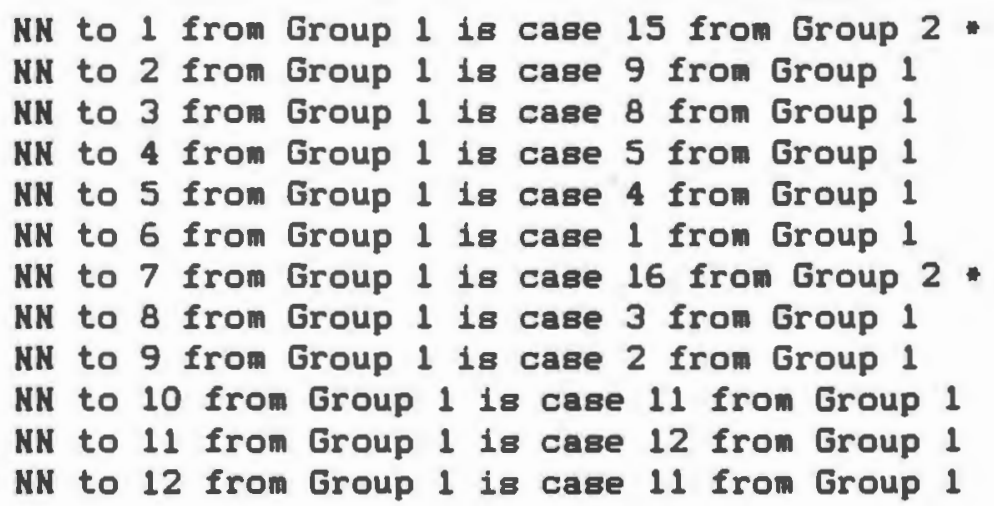

Group II: Virgin Island Samples

NN to 15 from Group 2 is case 1 from Group $1 *$
NN to 16 from Group 218 case 7 from Group $1 *$
NN to 17 from Group 2 is case 21 from Group 2
NN to 18 from Group 2 is case 19 from Group 2
NN to 19 from Group 2 is case 20 from Group 2
NN to 20 from Group 218 case 1 from Group $1 *$
NN to 21 from Group 218 case 22 from Group 2
NN to 22 from Group 2 is case 21 from Group 2
NN to 23 from Group 2 is case 24 from Group 2
NN to 24 from Group 2 is case 23 from Group 2

(Numbers 13 and 14 are unknowns and appear in Table 7)

Error Rate $=22.72728 \%$ 
Table 4. Transformed densitometry data for the 8 most prominent protein variables taken from electrophoretically separated and stained blood proteins of adult leatherbacks nesting in Costa Rica (samples 1-12) and the Virgin Islands (samples 15-24). Also included are two samples from two stranded leatherbacks of unknown origin (samples 13 and 14). The identities of the proteins represented by the data are not known.

Sample $*$ 1 2 3 4 5 6 7 8

C. $\mathrm{R}$.

$\begin{array}{rrrrrrrrr}1 & 20.80 & 19.95 & 25.93 & 8.57 & 14.65 & 13.45 & 5.33 & 15.62 \\ 2 & 19.40 & 22.81 & 25.05 & 8.80 & 11.268 & 9.69 & 10.11 & 19.73 \\ 3 & 26.97 & 22.91 & 25.59 & 7.55 & 9.90 & 10.89 & 5.23 & 18.83 \\ 4 & 21.52 & 20.38 & 23.86 & 7.27 & 8.07 & 12.49 & 7.55 & 23.10 \\ 5 & 15.07 & 17.90 & 16.54 & 11.08 & 13.14 & 14.65 & 7.82 & 16.92 \\ 6 & 13.91 & 22.03 & 17.29 & 11.63 & 11.98 & 12.98 & 8.07 & 16.15 \\ 7 & 16.67 & 16.54 & 12.66 & 11.45 & 11.27 & 14.06 & 8.32 & 15.89 \\ 8 & 13.91 & 18.95 & 21.22 & 8.07 & 9.69 & 11.63 & 8.34 & 16.54 \\ 9 & 21.01 & 15.21 & 14.50 & 9.69 & 12.49 & 12.66 & 12.15 & 4.94 \\ 10 & 12.66 & 13.91 & 27.48 & 9.69 & 14.65 & 16.02 & 6.98 & 11.45 \\ 11 & 16.28 & 22.42 & 26.97 & 13.45 & 11.81 & 10.70 & 9.03 & 11.98 \\ 12 & 15.62 & 20.09 & 20.59 & 8.80 & 12.49 & 9.90 & 6.05 & 26.63\end{array}$

Unknowns

$\begin{array}{rrrrrrrrr}13 & 31.08 & 35.63 & 21.82 & 8.07 & 9.48 & 8.32 & 8.07 & 15.62 \\ 14 & 22.52 & 13.14 & 19.73 & 9.90 & 12.98 & 16.28 & 8.07 & 10.70\end{array}$

V. I.

$\begin{array}{rrrrrrrrr}15 & 25.32 & 21.01 & 23.48 & 11.98 & 10.70 & 9.90 & 8.32 & 15.48 \\ 16 & 19.06 & 17.05 & 21.22 & 7.55 & 10.70 & 9.48 & 6.99 & 12.15 \\ 17 & 17.54 & 12.98 & 23.58 & 23.10 & 14.93 & 17.29 & 9.26 & 12.15 \\ 18 & 24.96 & 23.48 & 13.45 & 12.32 & 11.81 & 10.11 & 10.11 & 13.61 \\ 19 & 30.62 & 21.32 & 22.62 & 12.82 & 8.57 & 8.07 & 10.51 & 19.51 \\ 20 & 20.06 & 21.73 & 19.40 & 23.86 & 10.11 & 6.69 & 6.05 & 21.01 \\ 21 & 19.17 & 13.14 & 24.96 & 11.81 & 11.08 & 9.48 & 11.08 & 13.45 \\ 22 & 13.91 & 15.62 & 33.33 & 22.32 & 8.32 & 8.32 & 9.90 & 15.62 \\ 23 & 11.08 & 16.28 & 17.54 & 9.69 & 8.57 & 8.57 & 11.27 & 20.06 \\ 24 & 16.92 & 19.06 & 22.81 & 12.32 & 12.32 & 8.80 & 8.32 & 14.21\end{array}$


In the interest of parsimony, only the most highly discriminatory densitometry variables vere used for maximum likelihood solutions of the discrimination function. Using the two most discriminatory variables (protein peaks 3 and 5), or those that vere identified as most powerful in the stepwise analysis by the program, linear discrimination analysis shoved a clear division betveen subgroups. Adding one more variable (the third-most discriminatory as identified through the discrimination exercise) to the discrimination function caused a better fit; the null hypothesis that the densitometry values occurred independently of the subgroups vas rejected at the $p=.05$ level (Table 5). When posterior probabilities vere determined as a cross-validation, only two of the samples in the first group $(20 \%)$ and three of the samples from the second (25\%) vere misclassified using two discrimination variables (Table 6). Thus, two variables vere poverful enough to classify over 75\% of the samples correctly using discriminant analysis. The error rate was reduced significantly when more variables vere introduced into the discriminate function; hovever, given the small sample sizes, the risk of overfitting the data remains great if using more than two variableg (A. Solow, pers. com.).

In a separate but related nalaysis aimed at exploring the discriminatory pover of the protein parameters given samples of unkown origin, two samples vere taken from untagged adults stranded on a Massachusetts beach and captured in a Rhode Island pound net. These unknown samples vere statistically matched to the most probable stock through a maximum likelihood estimator (MLE) computer program 
Table 5. Discriminant functions generated from total protein stained isoelectric-focusing densitometry data from two groups of adult fewale leatherback turtle blood proteins, using the 3 most discriminatory variables (protein bands 3 (a), 5 (b), and 7 (c).

GROUP 1. COSTA RICA

$$
y=3.54 a+0.58 b+4.34 c-58.06
$$

GROUP 2. U.S.V.I.

$$
y=4.03 a+0.20 b+5.37 c-74.21
$$


Table 6. Results of forvard stepvise discriminant analysis of sea turtle blood protein data from densitometry readings. The resulta presented as number of correctly classified observations in each group. Stepvise discrimination analysis removes one case from the data set at a time, then uses best fit to the discriminant functions (Table 5) to match the case to a class. The three variables used in this stepvise analysis corresponded to protein bands 3, 5, and 7 of the elght most prominent peaks selected. Circled values indicate number of correctly classified cases for each nesting group.

Number of Observations Grouped in

Each Class Using Three Most

Discriminatory Variables
Groups
1
2

\begin{tabular}{|c|c|c|}
\hline $\begin{array}{cc}N=10 & 1 \\
& \text { U.S. V.I. }\end{array}$ & 7 & 3 \\
\hline Actual Clagses & & \\
\hline $\begin{array}{cc}N=12 & 2 \\
& \text { COSTA RICA }\end{array}$ & 0 & 12 \\
\hline
\end{tabular}


designed by $P$. Ihssen and F. Utter (Millar, 1987). Using the binary specific enzyme data (Table 1), both unknowns vere matched with $50 \%$ liklihood to the Virgin Islands population but showed no statistical affinity to the Costa Rica population. Given the small number of unknown samples used, this MLE test was used only to show the potential practicality of this technique.

The same unknown samples vere classified using the nearest neighbor technique mentioned above. Using the nearest neighbor classification technique on the densitometry data, the first unknown (Sample * 13) vas classified with the Costa Rican stock while the second (sample $\$ 14$ ) vas classified with the Virgin Island stock (Table 7). 
Table 7. Classification of two blood samples from stranded adult leatherback turtles of unknown origin. The blood proteins vere separated electrophoretically, stained for total proteins, and grouped on the basis of densitometry data by a nearest neighbor classification algorithm (James, 1985). Values used for the classification appear in Table 4.

Sample

13

14
Nearest neighbor

Case 3

Case 16
Sample group of nearest neighbor Group 1, Costa Rica

Group 2, Virgin Islands 


\section{DISCUSSION}

There are several lines of inquiry that my data address, all of which may have relevance to leatherback sea turtle population recovery and species management. The results can be used to address three fundamental questions about $\underline{D_{\text {. }}}$ coriacea population dynamics: 1 ) Is the North Atlantic Dcean leatherback population a panifictic assemblage or are these leatherback populations instead divided into not only seasonally spatial, but also genetically distinct denes between which there is little gene flov? 21 If the North Atlantic leatherback population is divided into true stocks, what levels of genetic variablity exist in the smaller subgroups and are those levels as dangerously lor as they are in other fragmented populations of endangered species? 3) Do existing differences in genetic makeup of stocks allov use of blood proteins as markers for stock identification when tagging studies are limited?

At least two, possibly more, stocks of leatherbacks occur in North Atlantic vaters. The denic structure I found in my genetic investigation is also supported by tag returns which indicate that adult females shor very little nesting site interchange. One leatherback tagged on Sandy Point, St. Croix, U.S.V.I. did visit the Culebra nesting beaches, but these areas are separated by less than 80 kilometers and this episode was deemed a rare event by researchers studying these nesting group intensively (Eckert and Eckert, 1988 ). Analysis of epifaunal encrustation of females nesting at Sandy Point also supports the notion of independent demes with little interchange and a high degree of nest site fidelity (Eckert and Eckert, 1988). 
The genetic information in my study suggests that not only do nesting females form geographic subgroups but that breeding males do so with the females. Such behavior directly contradicts the theory that leatherbacks assemble at central mating areas where members of different nesting subgroups interbreed as suggested by Lazell (pers. comm.). That an evolutionary strategy in which males exhibit migratory patterns different from those of females, and thus have to search for females in the open ocean, has developed in leatherbacks is difficult to imagine, and has no precedent in any other highly migratory marine species. More likely, males accompany females to the general vicinity of the nesting beaches, were they mate one or more times during the nesting season. The fact that copulating pairs have not been seen near nesting beaches, excepting one case near St. Croix where a presumed mating pair of leatherbacks was seen by a Division of Fish and Wildlife employee who was patrolling offshore (M. Tobias, pers. comm.) only suggests that leatherbacks may not mate close to shore. Because my data show clear genetic distinction between the Virgin Islands and Costa Rican nesting colonies, reproductive separation must exist between males of these colonies.

The results of this study should not be used to make generalizations about the demic structure of leatherback sea turtle populations elserhere. Tro important qualifications limit the general applicability of the findings: first, that samples vere not collected from all major nesting populations; second, that sample sizes vere small out of regulatory necessity. The optimal sample size question is difficult for many researchers, particularly those 
that rork with endangered or locally rare species. In this work with endangered and thus federally-protected D. coriacea populations, the sample size was restricted by legislative mandate and could not be 1ncreased. Regardless, Gorman and Renz1 (1979) shoved definitively that sample sizes in genetic studies such as mine vere less critical than the number of protein variables measured.

In my study of leatherback demic structure, although the assumption of normality could not be made with certainty, the relatively large number of parameters investigated in comparison to the number of samples obtained ensured that the discrimination analysis vas justified despite small sample sizes. It must also be stressed that the sample sizes represented relatively large proportions of the nesting populations. Thus $6 \%$ of the estimated population nesting in the vicinity of Parismina and a highly significant 25\% of the estimated St. Croix nesting group vere Bampled.

The sample size difficulty vas amplified vith my use of only tro samples from turtles of unknown origin. My purpose in doing the MLE and nearest neighbor classifications exercises was not to draw broad conclusions about the migratory movements of leatherbacks, but rather to demonstrate the usefulness of the discrimination analyses when good baseline information exists. The quality of this baseline information would be greatly improved by larger sample sizes from each of several additional nesting groups. This improved information vould make possible assignment of any captured, moribund, or freshly dead animal of unknown origin to the most probable stock, based on a gmall blood sample. 
Since the nearest neighbor method is preferable to the MLE when using small samples sizes (James, 1985), I place greater confidence in the nearest neighbor results and would recommend the analysis for future studies. Again, the small sample size for the unknown group, and secondarily, the sampled stocks, reduces the probability of a definitive outcome for the analyses performed in this study. Hovever, these methods hold great promise for stock identification of stranded leatherbacks, and the use of such analyses should be encouraged whenever possible. This approach can lead to an increased understanding of foraging areas for different stocks, migratory patterns, and the genetic makeup of sympatric demes.

That the Atlantic population of leatherbacks is subdivided into discrete stocks has important implications for management. Bolstering production in one segment of the population, for instance adult females of the small St. Croix - Puerto Rico stock, vill probably have little effect on the inclusive population size of the species. In other vords, beach-specific management efforts vill have only localized effects when population subdivision exists. Any recovery plan for the species, such as is mandated by the U.S. Endangered Species Act of 1973, must acknowledge this natural fragmentation. Also important is the concern that the local area has the resources to support and sustain a population increase if efforts are directed at increasing population size through so-called headstarting and hatchery programs. Many Caribbean nesting beaches have become marginal leatherback nesting sites because of development and recreational use (Meylan et al., 1985). If the population sizes are 
suddenly increased, the leatherbacks returning as adults to the natal beach may not find the beach of a quality that permits successful reproduction. This concern has already been volced with respect to the olive ridley (Lepidochelys olivacea) population nesting in Nancite, Costa Rica (Cornelius, 1986). Although the latter species nests en masse in events known as "arribadas" and may thus not serve as a valid basis for comparison, the future resource requirements of leatherbacks should be considered in any management program.

Consequently, each leatherback stock must be treated as a separate entity. In fact, because genetic distinction 18 so clearly exhibited by the two subgroups investigated, each stock should probably be preserved in an effort to maintain the greatest genetic diversity in the species as a whole. Lande (1988) described hov population subdivision can lead to maintenance of genetic variability in even drastically reduced populations. Such a mechanism could account for the relatively high level of heterozygosity in Dermochelye (see below), and strengthens the argument for maintaining each nesting population as a discrete entity. Resource managers should assess the genetic composition of each hypothesized stock and its potential for recovery, and then act in the most efficient vay possible to ensure that each stock is preserved. Such research and management action would be an assured way of realizing the goal of maximum liklihood of this species' survival.

There are other grounds for opting for a management strategy in which each population sub-group is protected. That Dermochelys coriacea populations utilize a geographically vide and ecologically 
diverse array of nesting beaches could counter the potentially distasterous effect caused by the loss of a single critical nesting area, such as could occur in the event of a natural catastrophe such as a severe storm or extreme sea-level rise. The Kemp's ridley sea turtle (Lepidochelys kempii) may be so severely endangered precisely because it nov relies on one major nesting beach, demonstrating the vulnerability of a restricted nesting locality strategy.

That the North Atlantic leatherback population is subdivided also suggests that the local stocks are closer to minimum viable populations (MVPs) in each subgroup than previously thought. Quantitative values for MVPs in leatherbacks have not been calculated, due in large part to the discrepancies in estimating age at first breeding, which have been hypothesized to be as low as 2-3 years (Rhodin, 1984) and as high as 30 years (Carr, 1952). Hovever, each fragment of the population must be closer to any hypothetical MVP than the sum total representing the Atlantic population as a whole (Soule, 1980). For this and the aforementioned reasons, I argue for increased urgency for the protection of each nesting population, despite strong local pressures to harvest leatherbacks for various products in some areas (Groombridge, 1982). Within the tro stocks studied, genetic variability of the polynorphic proteins vas surprisingly high when compared to other sea turtle species. The mean heterozygosity value as averaged across seven loci, 0.33, is far greater than found for green (0.12) or loggerhead (0.03) turtles (Smith et al., 1977). I cannot make direct comparisons since the higher resolution technique I used should reveal greater variability than the simpler starch gel 
electrophoresis technique of Smith et al. (1977).

Even small stocks such as the St. Croix nesting population show little evidence of inbreeding depression. In addition, the relatively high genetic variability found in the Dermochelyg populations studied indicates that no historical bottlenecking effect occurred, an inference consistent with what is known about historical exploitation of the species (Carr and Ogren, 1959).

The results of this study vary in their accordance with predictions made about adaptive variability described in theoretical models. The "coarse-grained" versus "fine-grained" models of adaptation presented by Leving (1968), models which vere later adapted for vertebrate comparisons by Valentine (1976), predict that large, highly migratory carnivores such as the leatherback should be highly homozygous. Hovever, other theories such as those elaborated by Selander and Kaufman (1973) predict that the leatherback, being an endotherm (Greer et al., 1973), vould have a higher genetic variability than ectotherms in general. In my estimation, validation of these theoretical models using only a fev proteins is not possible. Such comparisons are better made using extremely high resolution techniques such as DNA sequencing. Unfortunately, using even such highly objective analyses to prove or disprove evolutionary theory can be misleading, since the level of genetic variability observed is to some extent influenced by the choice of methodology employed by the researcher, who has an a priori expectation of how much variability there ought to be (R. Lewontin, pers. comm.)

The levels of resolution obtained in my study of the genetic 
variability of leatherback populations is sufficient to delimit stocks. Both of the methods used: the specific enzyme identification and total protein densitometry, supported the same conclusions about demic integrity of Atlantic subpopulations. Hovever, since the methods are backed by different theoretical models and assumptions, it is useful to compare them. Although the total protein densitometry anslysis yielded more quantitative information than the speciflc enzyme staining techniques, the specific staining data shoved statistically better discriminating pover. More importantly, the specific enzyme staining technique highlighted the differences in gene products. This quantitative information encoded by the binary data reflected a difference with a discernable genetic basis. The apecific staining data vere, therefore, more appropriate for estimating the stock affinity of the unknown stranded and trapped individuals. For these reasons, I suggest that others way wish to use the specific enzyme staining method, particularly when ample sizes are necessarily small (1.e. from endangered populations). The analyses used here should be expanded to more rigorously define the population structure of this and other sea turtles species. For the Atlantic population of Dermochelys coriacea, samples should be obtained from Panama, Columbia, French Guinana, Suriname, Guyana, and the Dominican Republic, all important and geographically distinct nesting sites. The blood samples should be analyzed using specific staining techniques and should be run under published conditions, thereby facilitating cross-comparison.

Also needed la a clear definition of the behavior of male leatherbacks, including the extent of emigration from one population 
subgroup to another, thus increasing gene flov. A related problem is whether females are polygamous within a single nesting season. One vay to address this question vould be to sample hatchlings from separate clutches laid by the same female and determine whether inter-clutch genetic variability is greater than within-clutch variability. If so, one could infer that the offepring vere fathered by different individuals, presuming that females do not store the sperm of multiple matings together, which is also possible. Similar questions about parentage have been addressed using electrophoretic analysis of blood proteins in other vertebrates (McCracken and Bradbury, 1977). Again, such a question has implications not only for gaining greater knowledge of the species but also for developing more effective management.

Dermochelye coriacea may be in danger from both localized population extinctions and gradual but irreversible extirpation. Perhaps more than any other sea turtle species, it requires a diversity of intact habitat types to survive, ranging from highly productive subarctic and temperate open ocean areas to varm, shallow vater and coastal tropical habitats. Comprehensively managing threats to this species could mean establishing corridors linking small protected segments of each habitat together in a system providing access to the entire set of marine ecosystems utilized throughout the individual home range. Although not explicitly stated, this is wat many conservationists are already attempting to do to through their diverse sea turtle recovery efforts. Each beach protection program, each legislative action mitigating the impact of 
fishing and shipping activities on feeding turtles, and each action taken to prevent marine habitat degredation effectively protects one link in the vital chain of habitats needed by endangered sea turtlea. But none of these efforts can be systematically beneficial if the most basic question of all, namely, "What is the population to be managed and hov does it vary in time and space?" is left haphazardly to idle speculation. 


\section{ACKNOWLEDGMENTS}

I express gratitude to those people that helped make my fieldwork enjoyable, especially John and Virginia Kollman, Robert Brandner and Sue Brasford, and the Earthwatch volunteers in St. Croix. Special thanks to C. Robert Shoop, Saul Saila and Suzanne Ayvazian, whose tireless offers of help and guidance did not go unheeded. This vork vas supported in part by a fellowship from the International Women's Fishing Association, a grant from the Society of Signa Xi, the Pew Charitable Trusts and the Marine Policy Center of the Woods Hole Dceanographic Institution. 


\section{LITERATURE CITED}

Agardy, M.T. 1989. An effective method to obtain blood from large sea turtles. Doctoral dissertation manuscript, University of Rhode Island.

Agardy, M.T. 1981. Preliminary report on the reproductive success of leatherback turtles at Sandy Point, St. Croix. Unpublished U.S. Fish and Wildife Service Report. Atlanta, GA.

Allendorf, F. and R. Leary. 1986. Heterozygosity and fitness in natural populations of animals. pp 57-76 In M. Soule, [ed.] Conservation Biology. Sinauer, Sunderland, MA.

Bacon, P., F. Berry, K. Bjorndal, H. Hirth, L. Ogren, and K. Weber, [eds.]. 1984. Proceedings of the Western Atlantic Turtle Symposium. Univ. Miami Presa, Miami.

Baker, G. 1980. Recovery plan: leatherback turtle (Dermochelye coriacea). U.S. Fish and Wildlife Service unpublished document. Wash., D.C.

Balasingham, E. 1967. The ecology and conservation of the leathery turtle Dermochelys coriacea in Malaya. Micronesia 3: 37-43.

Bels, V., F. Rimblot-Baly and J. Leacure. 1998. Croiseance et maintien en captivite de la Tortue Luth Dermochelye corlacea (Vandel11, 1761). Revue fr. Aquariol. 15 (1988). 
Boven, B., A. Meylan, and J. Avise. 1989. An odysery of the green turtle: Ascension Island revisited. Proc. Mat1. Acad. Sc1. USA 86: 573.

Brongersma, L.D. 1972. European Atlantic turtles. Zool. Verhand1. Leiden 121: 1-318.

Brown, B.E., G.H. Darcy, and W. Overholtz. 1987. Stock assessment / stock identification: an interactive process. Proceedings of the Stock Identification Workahop, 5-7 Kov. 1985, Panama C1ty Beach, Fla. NOAA Tech. Mem. MKFS-SEFC-199: 1-24.

Bustard, H.R. 1972. The leathery turtle. Oryx 11(4): 233-234.

Carr, A. 1952. Handbook of Turtles. Cornell University Presa: Ithaca, NY.

Carr, A. and L. Ogren. 1959. The ecology and migrations of sea turtles, 3. Dermochelys in Costa Rica. Am Mus. Nov. 1958: 1-29.

Cornelius, S.E. 1986. The gea turtles of Santa Rosa Mational Park. Fundacion de Parques Nacionales Costa Rica. 64pp.

Eckert, K. and C. Luginbuh1. 1988. Death of a giant. Marine Turtle Nevsletter 43: 2-3.

Eckert, K. and S. A. Eckert. 1983. Tagging and nesting research of leatherback sea turtles (Dermochelys coriacea) on Sandy Point, St. Croix, USVI, 1983. Final Report to the U.S. Figh and Wildlife Service. U. Georgia, Athens. 
Eckert, K.A. and S. A. Eckert. 1988. Pre-reproductive movements of leatherback sea turtles (Dermochelys coriacea) nesting in the Caribbean. Copeia 1988 (2): 400-406.

Fabrizio, M. 1986. Stock discimination in the striped bass, Morone saxitilis. Unpublished Ph. D. dissertation, University of Rhode Island, Kingston, RI.

Fretey, J. 1981. Tortues marines de Guyane. Editions du Leopard d'Or, Paris: 1-136.

Gorman, G.C. and J. Renzi, Jr. 1979. Genetic distance and heterozygosity estimates in electrophoretic studies: effects of sample size. Copeia 1979(2): 242-249.

Grant, W. and F. Utter. 1984. Biochemical population genetics of the Pacific herring (Clupea pallasi). Can. J. Fish. Aquat. Sci. 41: 856864.

Grant, W., D. Teel, and T. Kobayashi. 1984. Biochemical population genetics of Pacific halibut (Hippoglossus stenolepis) and comparison with Atlantic halibut ( $38: \quad 1838-1855$.

Greer, A.E., J. Lazell, and R. Wright. 1973. Anatomical evidence for a countercurrent heat exchanger in the leatherback turtle (Dermochelys coriacea). Nature 244: 181. 
Groombridge, B. 1982. The IUCN amphibia-reptilia red data book. Part 1. Testudines, Crocodylia, Rhyncocephalia. IUCN, Gland, Switzerland: 1-426.

Hart1, D. 1980. Principles of Population Genetics. Sinauer, Sunder land, MA 1-488.

Ihssen P.E., H.E. Booke, J. M. Casselmam, J. H. McGlade, N.R. Payne, and F.H. Utter. 1981. Stock Identification: materials and methods. Can. J. Figh. Aquat. Sci. 38: 1838-1855.

James, M. 1985. Classification Algorithms. J. Wiley \& Sons, KY.

Kleiman, D.G. 1980. The sociobiology of captive propogation. pp 243262. In M.E. Soule and B.A. Wilcox [eds.], Conservation Biology: An Evolutionary-Ecological Perspective. Sinauer Assoc., Sunderland, MA.

Lande, R. 1988. Genetica and demography in blological conservation. Science 242: 1455.

Levins, R. 1968. Evolution in Changing Environments. Princeton University Press: Princeton, NJ.

Lewontin, R.C. 1984. Detecting population differences in quantitative as opposed to gene frequencies. Am. Nat. 123(1): 115124.

Limpus, C., M. McLachlan, and J. Miller. 1984. Further observations on breeding of Dermochelys coriacea in Australia. Aust. Wildl. Res. 11 : 567-571. 
Lynch, C. B. 1977. Inbreeding effects upon animals derived from vild populations of Mus musculus. Evolution 31: 525-537.

McCracken, G.F. and J.W. Bradbury. 1977. Paternity and genetic heterogeneity in the polygynous bat, Phyllostomus hastatus.

Science 198: 303-306.

Meffe, G.K. 1986. Conservation genetics and the management of endangered fishes. Proc. Am. Fish. Soc. 11(1): 14- 23.

Meylan, A., P. Meylan, and A. Ruiz. 1985. Nesting of Dermochelys coriacea in Caribbean Panama. J. Herp. 19: 293-297.

Mrosovaky, M. 1987. Leatherback turtle off scale. Nature 327: 286.

O'Brien, S., M. Roelke, L. Marker, A. Merman, C. Winkler, D. Meltzer, L. Colly, J. Evermann, M. Bush, and D. Wildt. 1985. Genetic basis for species vulnerability in the cheetah. Science 227:1428-1434.

Parsons, P.A. 1971. Extreme environmental heterosis and genetic loads. Heredity $26: 470-483$.

Pritchard, P.C.H. 1971. The leatherback or leathery turtle, Dermochelys coriacea. IUCN Monograph 1: Morges, Svitzerland.

Pritchard, P.C.H. 1976. Post-nesting movements of marine turtles (Chelonildae and Dermochelyidae) tagged in the Guianas. Copela 1976: 749-754. 
Pritchard, P.C.H. 1982. Nesting of the leatherback turtle, Dermochelys corlacea, in Pacific Mexico, with a new estimate of the vorld population status. Copela 1982(4): 741-754.

Rhodin, A.G.J. 1985. Comparative chondro-oseeous development and growth of marine turtles. Copeia 1985: 752-771.

Ros8, J. 1982. Historical decline of loggerhead, ridley, and leatherback sea turtles. pp 189-195 In K. Bjorndal [ed.]. Biology and Conservation of Sea Turtles. Smithsonian Institution Press: Washington, D.C.

Saila, S. and B.K. Martin. 1987. A brief review and guide to some multivariate methods for stock identification. Proceedings of the Stock Identification Workshop, Nov 5-7, 1985, Panama City Beach, Fla. MOAA Tech. Mem. NHFS SEFC- 199: 149-174.

Selander R.K. and D.W. Kaufman. 1973. Genic variability and strategies of adaptaions in animals. Proc. Nat. Acad. Sci. USA $70(6): 1875-1877$.

Schulz, J. 1975. Sea turtles nesting in Surinam. Zoologische Verhandelingen 143: 1-141.

Shoop, C.R., T.L. Doty, and M.E. Bray. 1981. Sea turtlea in the region between Cape Hatteras and Nova Scotia in 1979. pp IX: 2-89 In: A characterization of warine mammals and turtles in the mid- and North Atlantic areas of the U.S. Duter Continental Shelf. Annual Report for 1979, CETAP: Kingston, R.I. 
Smith, M. H., H. O. Hillegtad, M. N. Manlove, D. O. Straney, and J. M. Dean. 1977. Management implications of genetic variability in loggerhead and green sea turtles. Proceedings of the 13th Congress of Game Biologists: 302-312.

Snedecor, G. W., and W. G. Cochran. 1980. Statistical Methods. Iova State University Press, Ames, Iova: 290.

Soule, M.E. 1980. Thresholds for gurvival: maintaining fitness and evolutionary potential. In M.E. Soule and B. A. Wilcox [eds.]. Conservation Biology: An Evolutionary-Ecological Perspective. Sinauer Assoc.: Sunderland, MA: 151-169.

Utter, F. 1987. Genetic estimates of stock compositions of 1983 Chinook salmon, Oncorhynchus tehavytecha, harvests off the Washington coast and Columbia River. Fish. Bull. 85(1): 13-23.

Valentine, J. 1977. Genetic strategies of adaptation. In F. Ayala [ed. ]. Molecular Evolution. Sinauer AB8oc. : Sunderland, MA: 78-94. 


\section{MANUSCRIPT * 2:}

AN EFFECTIVE METHOD TO OBTAIN BLOOD SAMPLES FROM LARGE SEA TURTLES 
AN EFFECTIVE METHOD TO OBTAIN BLOOD SAMPLES FROM LARGE SEA TURTLES

Obtaining blood samples from sea turtles is becoming increasingly crucial activity for addressing questions about physiology, reproductive biology, genetics, and population dynamics. For small species, such as the ridley turtles (Lepidochelys kempii and Lepidochelys olivacea), or for juveniles and subadults of larger species, blood may be obtained using the technique of Orens and RuIz (1980). Their method involves using 21-25 gauge hypodermic needles and an optional angled restraining table in sampling blood from the dorsal cervical sinus. Such blood sampling clearly preferable to cardiac puncture via limb (Friar, 1977) or plastral insertion (Dozy et al., 1964), or to post-sacrificial bleeding, since both of these formerly common methodologies involve significant trauma. Hovever, the blood sampling technique of Ovens and Ruiz (1980), using relatively small gauge needles for sampling from the neck region, is not effective for large loggerhead (Caretta caretta) or leatherback (Dermochelys coriacea) sea turtles, due to large neck girths and the depth of the cervical sinuses. Attempts to obtain blood from the paracervical sinus of leatherbacks vere so often unsuccessful that the U.S. Fish and Wildlife Service actively discouraged researchers from continuing sampling efforts (S. Furness, pers. comm.). Blood rork on this species has thus been limited.

A relatively easy and extremely efficient method to withdrav blood from Dermochelys and Caretta is to use a 13 gauge spinal tap needle. These needles are 5 centimeters long, have a highly beveled 
tip, and can be inserted into the neck of any large sea turtle specimen without any spparent discomfort to the animal. This is an especially important consideration since samples are most easily obtained during the period when females are depositing eggs. Traumatizing females during the breeding season might cause physiological or behavioral interference with reproduction, which must be avoided with endangered species.

Both the needle and the syringe barrel should be coated in heparin before insertion to avoid clot formation, since sea turtle blood coagulates very quickly when exposed to air. Sampling may be done only on relatively still individuals, such as nesting females that have deposited their eggs but have not begun covering the nest. The needle should be inserted in the paracervical region of the neck just lateral to the vertebral column (Figure 1). The needle must be perpendicular to the dorsal plane of the neck (approximately vertical when the animal's head is resting on the ground). Suction should be applied to the syringe as the needle is inserted to its base and during withdraval. Blood is most easily obtained frow the paracervical sinus as the syringe is pulled upvards and the needle travels through the sinus.

Trenty-four, $10 \mathrm{ml}$ blood samples vere obtained from adult female leatherbacks nesting in Costa Rica and the U.S. Virgin Islands and over thirty $5 \mathrm{ml}$ samples vere collected froll loggerheads nesting in Mexico (Agardy, 1988) using this method. The majority (40) of the turtles sampled vere tagged and observed up to 2.5 months after sampling, and none shoved after-effects or complications frow the 


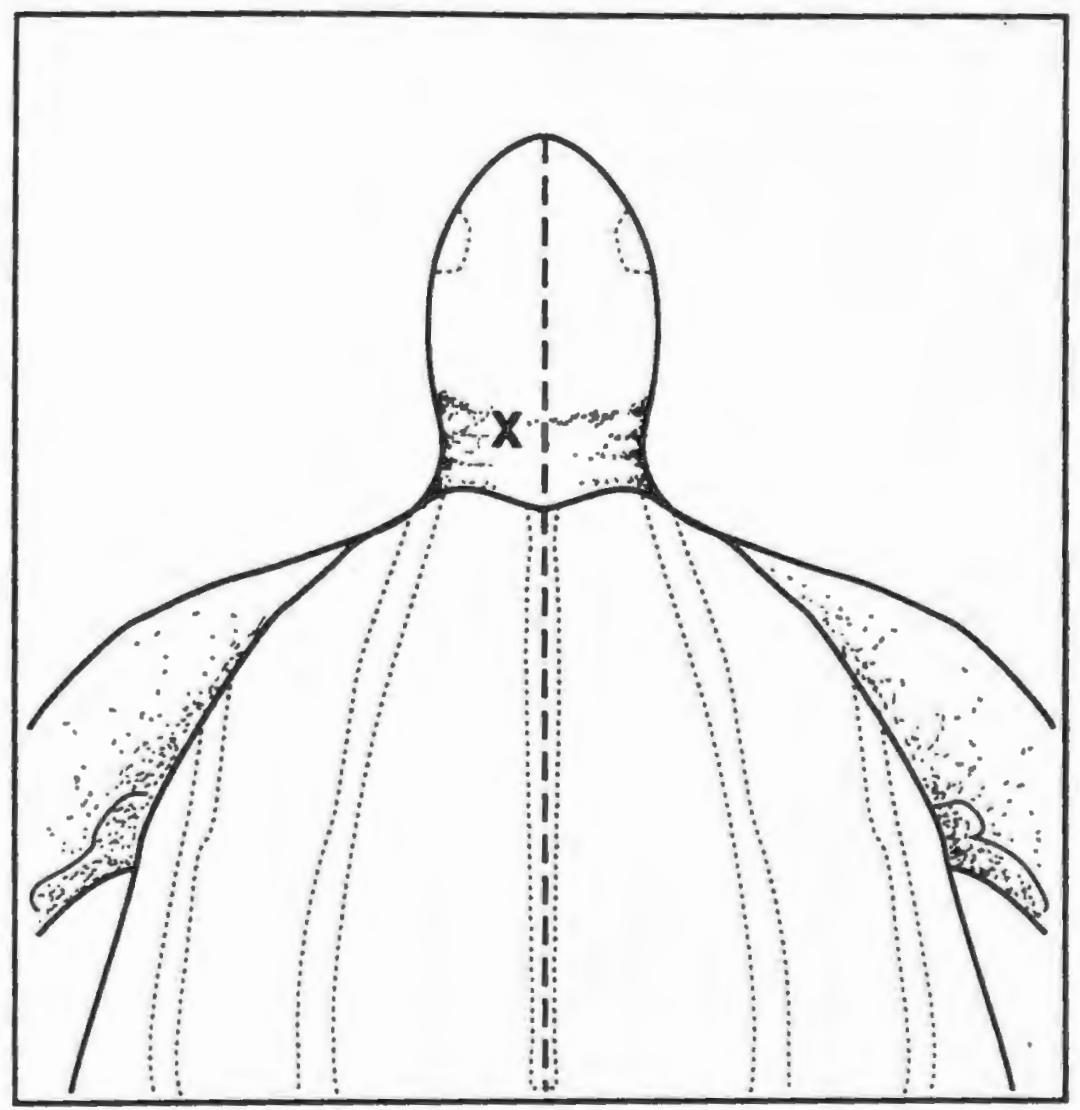

Figure 1. Needle insertion point for blood sampling from adult
leatherback turtles. 
technique. Blood samples can be stored for later use in vacutainers containing ETDA as an anticoagulant. 


\section{LITERATURE CITED}

Agardy, M.T. 1988. Blology and conservation of sea turtles nesting In Quintana Roo, Mexico, 1988. Report to U.S. Fish and Wildlife Service, Albuquerque, К. К.

Berkson, H. 1966. Physiological adjustments to prolonged diving in the Pacific green turtle (Chelonia mydar agase1z11). Comp. Biochem. Physiol. 18: 101-119.

Dozy, A. M., C. A. Reynolds, J. H. Still, and T.H. Hulaman. 1964. Studies on animal hemoglobins. I. Hemoglobins in turtles. J. Exp. Zool. 155: 343-347.

Friar, W. 1977. Turtle red blood cell packed volumes, sizes, and numbers. Herpetologica 33: 167-190.

Orens, D.W. and G.J. Ruiz. 1980. New methods of obtaining blood and cerebrospinal fluid from marine turtles. Herpetologica 36: 1720. 
MANUSCRIPT * 3:

WHY IMFORMATION ON POPULATION DYMAMICS IS CRITICAL TO THE CONSERYATION OF ENDANGERED SPECIES: LESSONS FROM SEA TURTLE RECOVERY ATTEMPTS 
WHY INFORMATION ON POPULATION DYMAMICS IS CRITICAL TO THE CONSERVATION OF ENDAKGERED SPECIES :

LESSONS FROM SEA TURTLE RECOVERY ATTEMPTS

\section{ABSTRACT}

Managers of endangered animal populations are often faced with the task of making management declaions vithout the luxury of having complete knowledge about the species. The problem is eapecially acute In cases where the body of knowledge about an animal's ecology pertains only to a certain portion of 1 to life cycle. Sea turtle recovery efforta are a perfect case in point: managers vorldvide are struggling to prevent local and sometimes global extinctions while knoving little about the species' demographic parameters, beyond that which is know about nesting females and ewergent hatchlings. Hovever, the total time that a sea turtle spends on land vithin the realm of convenient study is less than one percent of its life span.

Given that resources to study sea turtle ecology are limited and that time, especially for some critically endangered speciea, is short, managers must be presented vith the kind of information necessary for formulating efficient recovery attempts. In the case of highly migratory warine animals such as sea turtles, the nost important ppopulation data are the folloving: 1) what is the aize and extent of the population unit to be managed?, and, 2) what 18 that population's intrinsic rate of increase and hov is it prevented from being fully realized? Without answers to these basic 
prerequisite questions, other data collected on the biology of the animals cannot be framed in an accurate context for developing sound management. 


\section{INTRODUCT ION}

There is a Hungarian colloquialiam that can be loosely translated to mean "those that vork the hardest are those that have to". In Hungary the expreseion vas used long ago to justify a certain smugness exhibited by those who lived quite vell vithout seeming to have expended wuch effort. But it can also mean the reverse that in critical situations, hard vork is demanded, and that In such situations half-hearted or misdirected efforts are Insufficient and sometimes even counterproductive. For those who focus their attention on the recovery of endangered species, hard vork is an unconditional and accepted necessity. Buying time to gain more complete knovledge is a luxury that may be afforded in basic research but which is of little use in developing the applied scientific tools needed for crisis management. Those vorking to save a species from extinction are under more pressure to be efficient despite a limited information base, and they thus vork harder because they must.

The management of gea turtleg, those pantropically threatened marine reptiles vhich have become the center of much conservation activity and environmentaliat interest, provide a salient example of hov geveral recovery attempts and a great deal of hard vork may be vasted because critically important information about species dynamice is lacking. I illustrate this possibly unpopular opinion vith a description of the case of the leatherback turtle, Dermochelys coriacea, in the North Atlantic Dcean. 
The leatherback is extraordinary in many regards. Unlike the other species of shelled sea turtles that comprise the family Cheloniidae, the leatherback sea turtle is the only living species in the family Dermochelyidae and has a skin-covered shell. Hovever, it shares some morphological characteristics vith its super-familial cohorts, namely a streamlined body and flippers as adaptations for aquatic locomotion, a non-retractable head, and terrestrial egg deposition and incubation. Beyond these similarities the leatherback is distinctive from other sea turtle species in the following features: a "soft" shell which lacks the keratinized laminae found in other sea turtle species (Frazier, 1987), a tough dermis including a mosiac pattern of bones embedded in the tough connective tiseues of the skin, a counter-current heat exchanger which allovs the animal to maintain 1 tg body temperature at least $18^{\circ} \mathrm{C}$ higher than the ambient vater temperature (Greer et al., 1973), large keratinized buccal and esophageal papillae, an elongated esophagus used for food storage, proportionally large anterior flippers, and the enormous size of the adult animal, sometimes exceeding 900 kilograms (Eckert and Luginbuhl, 1988).

There are also behavioral characteristics exhibited by the leatherback not common to the green, Kemp's ridley, havksbill, or loggerhead turtles with which it shares Atlantic vaters. These include more extensive migrations from tropical nesting grounds to temperate and even sub-arctic vaters (Lazell, 1980), 1ts extensive feeding on medusold Jellyfish such as Cyanea capillata (Brongersma, 1972), and deep-diving to depths exceeding 780 meters (Eckert et al., 1986). The long distance movements and predominantly pelagic 
lifestyle of the species, are directly related to its unusual food preference, explain why even less is known about the biology of leatherbacks than about the other sea turtle species.

What is knovn about the leatherback turtle comes from disparate bits of Information about its marine ecology (Eckert and Eckert, 1988; Laze11, 1980); extensive data recording certain aspects of its terrestrial ecology such as nesting behavior and egg survivorship (Deraniyagala, 1939; Whitmore and Dutton, 1985; Hirth and Ogren, 1987: and Pritchard, 1971), especially in some vell-studied areas; and fragmentary historical records about 1 ts abundance and apparent population decline (Carr, 1952; Ros8, 1982). The animal is considered endangered throughout its range in all the vorld's oceans (Groombridge, 1982), although estimates of historical population size and even current numbers are extremely tenuous. What eatimates have been made (Pritchard, 1982) are based on beach aurveys during the nesting season and some short-term time series data obtained from tagging atudies. But it is not certain that all the vorld's major leatherback neating beaches have been discovered, and ve knov nothing about the population sizes of the majority of demographic sectors, Including adult males, non-breeding females, juveniles, and hatchlings beyond one to one day of age.

The sequential revisions of Dermochelye vorld population eatimates made in the last thirty years illustrate our ignorance of the species. In 1961, Fitter (1961) estimated the population as being composed of only 1000 breeding pairs. By 1971, that estimate had been revised upvard over fifty-fold vhen Pritchard estimated the 
number of breeding females at 29,000 to 40,000 individuals. Folloving the discovery of a major nesting ground in Pacific Mexico, Pritchard (1982) changed his estimate to 115, 000 mature females vorldvide. Verification of these estimates is lacking, hovever. A quick glimpse at this kind of demographic record might give the mistaken impression that the leatherback turtle population is growing at a fast rate, rather than diminishing. Hovever, the apparent increase reflects more the elusive nature of the critical data rather than any trend in population size. Ross (1982) extensively documented the decline of the leatherback in specific breeding agggregations, and he and other authors (Meylan et al., 1985; Pritchard, 1982) conceded that the leatherback's endangered status is varranted.

The decline of Dermochelys coriacea may be attributed to several compounding factors. In addition to the grave impacts caused by accelerated 1088 of nesting habitat, possible interference vith migratory and feeding behavior, and probable increases in the natural predation induced mortality of eggs and young, the leatherback has suffered increasing rates of slaughter at the hands of man. Although never hunted in large numbers for its meat, leatherback oil has been treasured as a cure for everything from arthritis to head colds, and is comonly used as a lubricant (Bustard, 1973; Carr, 1971 ). Inhabitants of many Caribbean islands have nov turned to leatherback meat as a supplement to ever-decreasing supplies of meat from preferred species (Meylan, et al., 1985). Leatherback meat may even be eaten by Inuits of Baffin Island in lean times (Shoop, 1980). Around the vorld leatherback eggs carry the cross-cultural and 
decidely dubious distinction of commanding a high price as aphrodisiacs, and both the legal and black market trade in eggs is thriving (Meylan et al., 1985). Furthermore, anthropogenicallyinduced, indirect impacts on the population, such as collisions vith ships, entrapment in fishing gear, morbidity and mortality from contact vith oll and tar, and death from the ingestion of plastic and other debris, continue to rise at an alarming rate (Balasz, 1985; Carr, 1987; and Laist, 1987).

The leatherback turtle appears threatened vith extinction. But if this or any other sea turtle species does go extinct, it vill not be for ront of human concern. Much recent environmentalist interest is focused on sea turtles (Canin, 1989), which may nov rival vales as the symbolic object of pity and advocacy (R. Mckanus, pers. comm.). The rise in public avareness and the international interest in endangered species protection has helped promote sea turtle conservation projects around the globe (IUCN General Assembly Report, 1988). But are these efforts aimed at recovering sea turtle populations 8 s efficiently and quickly as possible? I argue that in the case of Dermochelys coriacea they are not, because some of the most fundamental and critical questions about the species have neither been asked nor ansvered.

Management practices determine vhere problems are and aim to deduce what the causes of those problems might be. In the case of endangered species management, the problem 1s obvious: a dovnvard demographic trend that threatens to bring the population dangerously near the minimum size needed for its self-perpetuation (the minimum 
viable population size). The problem statement is accepted a priori. This is the case in the managment of the leatherback turtle in the North Atlantic region. But the target for possible management is unknown. Whether it is the vorldvide population, the species as a wole, the population found vithin an ocean basin, such as the Atlantic, or the female population that returns on one to three year cycles to a particular nesting beach has not been elucidated. Without defining the population to be recovered as a management unit, with respect to its size, extent and dynamics, a manager cannot hope to begin the kind of efficient recovery plans that the situation desperately demands. 
POPULATION DYMAMICS IMFORMATION AS CRITICAL TO MAMAGEMENT

The field of population biology concerns itself vith hov a group of organisms move, change, and replace themselves in space and time. These are the dynamics that need to be investigated for a population, or management unit, to be defined. We are exceedingly ignorant about the population biology of the leatherback turtle. Whether the Morth Atlantic population is contiguous or comprised of independentlyfunctioning demes is unknovn. We knov that breeding females exhibit nest site fidelity, are iteroparous, and return to the same beach to lay eggs, sometimes over several seasons. In this regard, then, ve know that at least some of the time segments of the Atlantic population are subdivided. But until recently it was not known whether the subdivision corresponded to true demic segregation: a genetically rather than temporally defined subdivision.

We also do not know what the rate of population replacement is in any population ve define. At least some of the factors that prevent this natural population replacement rate (whatever it may be) from being realized have been elucidated, albeit not systematically. But the tro most fundamental questions are those concerning the definition and intrinsic dynamics of the population to be recovered, and these have been ignored in the fervor to save this species from extinction. And because they have not been addressed, ve cannot Judge the efficiency of any management activities to know if they are helping to boost the Atlantic population as a vhole, or merely protecting a small local population, or, in the extreme, not helping at all. 
For the management of the Atlantic population of leatherbacks to be planned effectively vith a sound rationale, a study of the species' population dynamics is a first order-exercise. Assuming consensus concerning the nature and severity of the decline in numbers, a program aimed at providing the necessary information to managers might aim to address the following questions in the following order:

1) What is the size and extent of the population to be controlled or recovered - in other vords, what is the managenent unit?

2) What is the population replacement rate of this management unit?

3) What are the natural and anthropogenic factors interfering with the natural rate of replacement? And wat factors must be considered to enhance or maintain normal genetic variability in populations with reduced sizes, recognizing that the fitness of a population is as, if not more, important as its size?

4) Which of the above factors can be controlled through management measures and vhich of those vill yield the fastest, most tractable results?

Complete knovledge about a species is not a prerequisite for elaborating the demography of a population or modeling trends in population size. The population units themselves can be defined using sophisticated techniques that do not require enormous amounts of data collection time, and models can be developed relatively easily which can be used to generate predictions of the population's 
dynamics over time. Conservation blologists already acknovledge the value of such rork, however in most cases this message has not been relayed to natural resource managers or administrators (Lande, 1988). 


\section{LEATHERBACK SEA TURTLE POPULATION STRUCTURE}

Leatherback turtleg, although relatively rare in occurrence, are ubiquitous in North Atlantic and Caribbean vaters (Shoop et al., 1981). During the spring and summer breeding sesson, leatherback females come ashore to nest in Costa Rica (Hirth and Ogren, 1987), Panama (Meylan et al., 1985), Columbia (Ross, 1982), French Guiana (Fretey and Lescure, 1979), Dominican Republic (Ross and Ottenvalder, 1983), and some of the Lesser Antilles (Figure 1). Several other Caribbean localities support fever numbers of nesting fewales (Groombridge, 1982; Pritchard, 1971). Aerial surveys shov that leatherbacks are also found in offshore vaters from Cape Hatteras to Nova Scotia (Shoop, 1987; Shoop et al., 1981), Cape Hatteras to Key West (Thompson and Shoop, 1983), and in the Gulf of Mexico (Fritts et al., 1983). In the summer and fall months, some leatherbacks become entrapped in various kinds of fishing gear set in temperate vaters (Goff and Lien, 1988). During the same time of year, dead and moribund animals are found vashed ashore along the eastern seaboard of the United States and Canada, particularly in Kev Jersey, Nev York, Kev England, Kova Scotia, and Nevfoundland. The normal home range for this species thus appears to extend over 5000 kilometers (Pritchard, 1976), with hypothesized migration routes (Lazell, 1980) carrying individuals from tropical nesting sites to sub-arctic feeding areas (Figure 2 ).

The North Atlantic population of leatherback turtles has been assumed to be a panmictic assemblage with only seasonal segregation related to breeding patterns. Conservation attempts in the Atlantic 


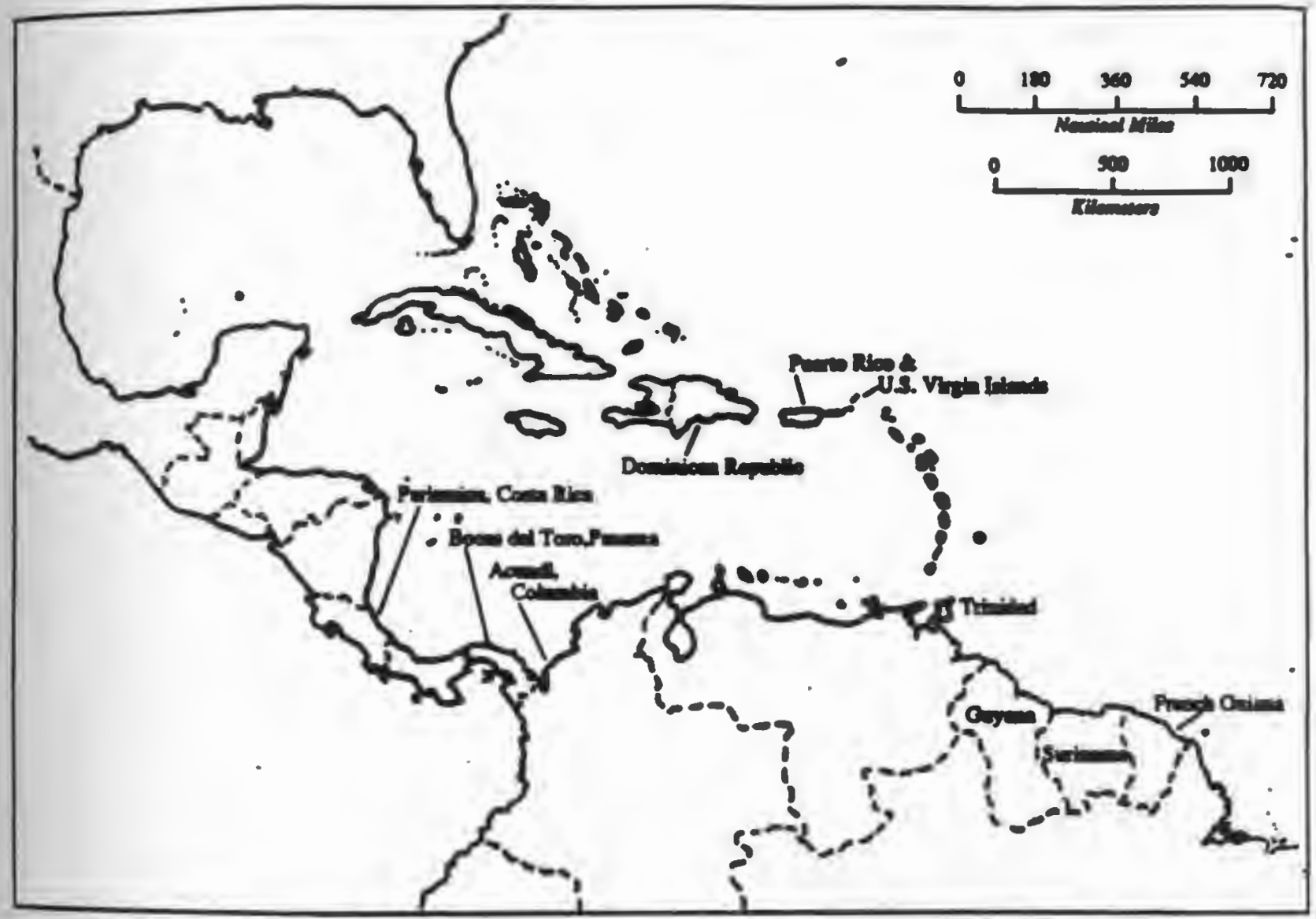

Figure 1. Major neating beachea uaed by Dermochelyg coriacea in the Caribbean region 
Pages are numbered incorrectly, No page 81 


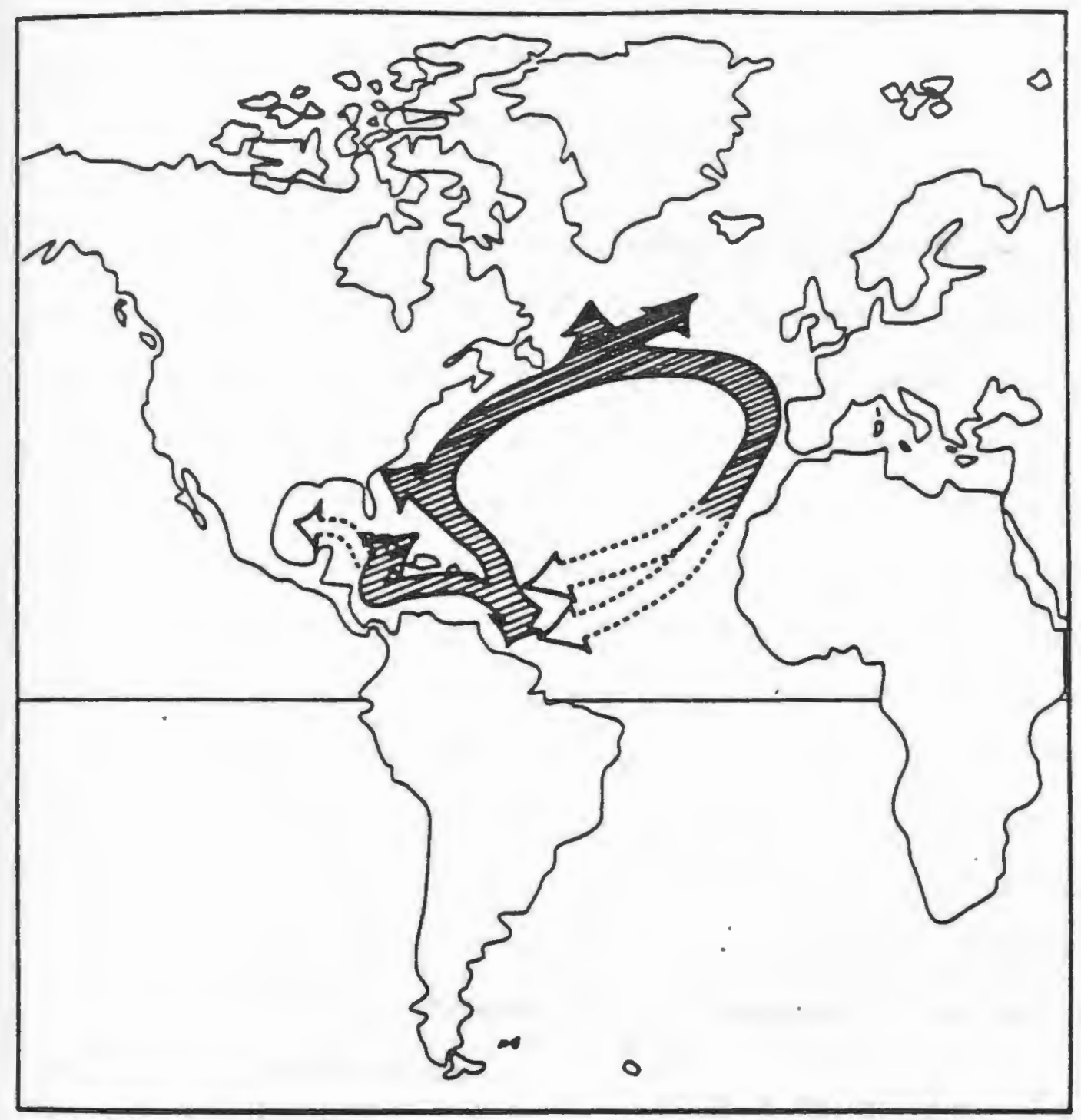

Figure 2. Hypothesized migration routes for the leatherback turtle (after Laze11, 1980). 
and Caribbean region, on the other hand, have alvays been piecemeal and directed as if tovards discrete but local population units. The discrepancy between these two underlying assumptions is obvious. Yet no literature record exists which defines any Dermochelys population as a management unit.

I attempted to resolve this problem for two videly separated nesting populations using electrophoretic analysis of blood proteins to determine whether separate leatherback nesting populations vere genetically distinct. The resultant data and analyseg did not support the null hypothesis that the Costa Rica and Virgin Islands nesting groups constituted geographical extremes of a contiguous Atlantic population (Agardy, 1989a). Ny data suggested the Atlantic population of leatherbacks is actually comprised of at least tro, although probably many more, discrete demes. This clearly implies that any management efforts must take the genetic delineation into consideration. More than one management unit exists, but hor many units requiring independent but coordinated conservation efforts has not been determined. The definition of management units certainly merits immedlate attention.

How can the Atlantic populations of Dermochelys coriacea best be delineated and defined? I suggest that the most cost-effective and time efficient method is to employ techniques that elucidate genetic structure of the nesting populations. Fisheries biologists commonly use genetic analyses to elucidate stock structure, but their task is often simplified by the ease vith wich enormous numbers of samples can be collected. Hovever, there are statistical tools which make it 
possible to hypothesize stock structure with a high degree of confidence even when sample sizes are small. SIMCA, a multivariate discrimination program developed for analytical chemistry, is one such method (Saila and Martin, 1987). There are numerous other discrimination techniques that also may be applied, including the stepvise discrimination method that I chose for the leatherback stock identification rork (Agardy, 1989a). Although the sample sizes rere necessarily small in the leatherback study due to regulatory restrictions on number of samples permitted, the analysis proved rigorous. Additional support for using such algorithms despite fev sample is provided by Gorman and Renzi (1979) vho contend that small sample sizes vill not distort estimates of genetic heterozygosity as long as many loci are investigated.

Electrophoretic analysis of blood proteins can be an effective vay to look at demography through the eyes of genetics. Blood can be sampled easily from leatherbacks using a 13-gauge spinal tap needle inserted into the paravertebral sinus of the neck (Agardy, 1989b). Only small amounts of blood are needed for electrophoretic analysis (3-5 ml), and sampling appears to have no ill-effect on adult turtles. Blood is most easily dravn from nesting females that have completed egg-laying, but blood may also be sampled from captured or stranded animals.

There are a number of alternatives a researcher can choose vhen analyzing blood proteins electrophoretically; these include looking for known allelic variants of metabolic enzymes (specific staining technique) or investigating all the proteins present in the sample vithout knoving speciflcally what their genetic correspondence might 
be (general protein densitometry). The advantages of the former method are that immediate visual results are produced and that the data can be used in estimating inbreeding coefficients. On the other hand, the advantage of the total protein method is that it generates a large data set, making more statistically poverful statements possible.

Aspects of population genetics are extremely important in the applied field of conservation biology. When population numbers are low, as they are de facto in endangered species, inbreeding and genetic drift effects which lead to increased genetic homozygosity must be monitored. Though demography is probably more important a science for conservation than genetics (see Lande, 1988), genet1c research is one way to describe the demographic characteristics of open populations.

Do using the tools of genetics constitute the best vay to gain critical information about sea turtle demography? Probably yes, if efficiency is a consideration. There are other vays to define sea turtle populations, hovever, and some have been practiced for many years. The most common method used to discern stock structure is through the tagging of adult females. Monel or Inconel cattle eartags are affixed to the trailing edge of either the front or rear flipper (or both) of a terrestrially nesting female. Long experience vith tagging has refined the methods used, so now large numbers of turtles are tagged each year with little disturbance to the animal and, typically, only moderate tag loss. The problem with this technique is that it is time intensive. True stock structure can 
only be determined through saturation tagging (marking all available individuals) over an extensive area and "recapturing" marked individuals year after year to determine adult turnover rate (arte of replacement or recruitment). And since only nesting females can be tagged in large numbers, tagging provides little information about the other segments of the population.

Recent technological advanceg could allow marking hatchling sea turtles with implanted microchip or passive transponders. Though feasible, the methods are inherently limited. Hatchling and fuvenile sea turtle natural mortality is presumably so high that huge numbers of young need to be tagged for the recapture of even a few adults, and these microchip tags are currently very expensive. Add to that the time horizon needed to obtain results; leatherbacks may take thirty years or more to mature (their growth rate is highly controversial). Thus saturation tagging of hatchlings requires the presence of researchers at the natal and nearby nesting beaches many years after tagging. In the meantime, 1mproper management measures could theoretically hinder the species' recovery.

There are tracking methods which allow migratory and local movements of a tagged individual to be monitored directly. These include conventional radiotracking methods from the surface or by satellite (e.g. Standora et al., 1984). The drawback of these methods is that they require extensive field observation and cannot be performed on large numbers of animals at once without exorbitant operating costs. Furthermore, location alone will not provide adequate information to delineate stocks or elucidate demography. 
Another method being currently investigated as a possible tool for defining stock structure of sea turtles is mitochondrial DNA (mtDKA) analysis (Boven et al., 1989). The underlying assumptions and the basic techniques used are similar to those used in conventional electrophoretic studies, but the genetic material of cells rather than their products is analyzed. Mitochondrial DHA is easily obtained from sea turtle tissues, especially from high metabolic tissues such heart, liver, and other organs (Avise, 1987). Since mtDKA analysis is a higher resolution technique than conventional electrophoresis, and since it looks directly at the genome, it is necessarily less subjective than the latter technique. Hovever, mtDNA analysis has two serious shortcomings when used to study sea turtle population structure : 1) sampling usually requires sacrifice of the animal, and 2 ) it does not shed light on the population genetics of males since mtDNA is maternally inherited. Electrophoretic analysis of the metabolic enzymes present in Dermochelys coriacea blood remains the fastest, most effective method of elucidating stock structure and defining the demographic unit in need of sound management. When this information 18 supplemented by data generated from other kinds of study, including mtDNA analysis and tag return statistics, a valid and rigorous basis for instigating management can be egtablished. 
ESTIMATING THE NET REPLACEMENT RATE OF SEA TURTLE POPULATIONS

Once the management unit has been identified and a clear picture of population movements emerge, the next information needed by a resource manager is an estimate of the rate of replacement for the population $\left(R_{0}\right)$. For an organism that spends each stage of its life vithin the realm of scientific observation, the natural mortality in each age group can be readily quantified. The case is infinitely more complex for sea turtles, since the animals spend only a fraction of their lifetime in areas where they can be easily studied, and since offspring cannot yet be followed to maturity. For some species such as the green turtle, Chelonia mydas, some life table information can be obtained from intensive studies at nesting beaches and in places where the animals are kept in captivity (Bjorndal, 1980; Thompson, 1980). Since leatherback sea turtles cannot be held in captivity for long periods (Bels et al., 1988) and because they are highly migratory, little definitive information on survivorship exists.

Given the crucial need for this type of demographic information and the lack of knovledge about leatherback blology, significant scientific effort should be invested in demographic studies. Simulation models with different mortality rates at different life history stages or different rates of grovth lead to astonishing predictions and further emphasize the need for verified demographic estimates. For instance, if one assumes that the survivorship pattern in leatherbacks is similar to that of other sea turtles that 
are better known, such as the loggerhead, Caretta caretta, (Frazer, 1983), a hypothetical life history table can be constructed for modeling vork (Table 1). From Leslie matrix model simulations using these data (Appendix B), results indicate that the most important population sectors for Increasing population grovth are the hatchling, juvenile and nevly mature age classes. For instance, by changing the survivorship parameter for hatchlings by a mere $10 \%$ increase in value, the simulated population grovth trend changes dramatically from a gradually declining population heading tovards extinction to a relatively stable but slightly increasing population (Figure 3). Various scenarios incorporating different survivorship values for all stage classes are given in Table 2; estimated lamba values less than one indicate population decrease and eventual extinction, greater than one population increase and recovery. These results are consistent with those demonstrated in loggerhead sea turtle population simulations (Crouse et al., 1985 ). For this more rigorous modeling exercise, a data set on the reprodutive biology of loggerheads nesting on Little Cumberland Island, Georgia, was combined with survivorship estimates calculated for the same population (Frazer, 1983) to generate a stage-based population model. This vork also implies that if the hypothesized demographic parameters used for modeling are accurate, the most critical component of the population for replacement value is the large juventle age class.

In my hypothesized leatherback population simulations, the resulta are based on the assumption that the rate of grovth is slow, with leatherback females taking 20 years or more to achieve 
Table 1.

Hypothetical life history parameters for Dermochelys coriacea, used as the basis for Leslie matrix simulations. This table includes: $1[x]$, survivorship from the egg to any subsequent stage; $p[x]$, stage to stage survivorship; $m[x]$, number of eggs deposited every two years by each breeding female divided by two (assuming a $1: 1$ sex ratio of offepring); and $R$, the finite rate of population increase, where $R_{0}=1[x] m[x]$.

$\begin{array}{lcccc}\text { Stage } & 1[x] & p[x] & m[x] & 1[x] m[x] \\ \text { Egg } & 1.00 & .85 & 0 & 0 \\ \text { Hatchling } & .0425 & .05 & 0 & 0 \\ \text { Young Juveniles } & .0043 & .10 & 0 & 0 \\ \text { Older Juveniles } & .0006 & .15 & 0 & 0 \\ \text { Neophyte Breeders } & .0005 & .90 & 220 & .132 \\ \text { Remigrants } & .0004 & .80 & 220 & .110 \\ \text { 3rd Time Breeders } & .0003 & .70 & 220 & .088 \\ \text { 4th Time Breeders } & .0002 & .60 & 220 & .044 \\ \text { - } & & & & \end{array}$

$R_{0}=.374$ 
Leslie Matrix, Leatherback Turtles
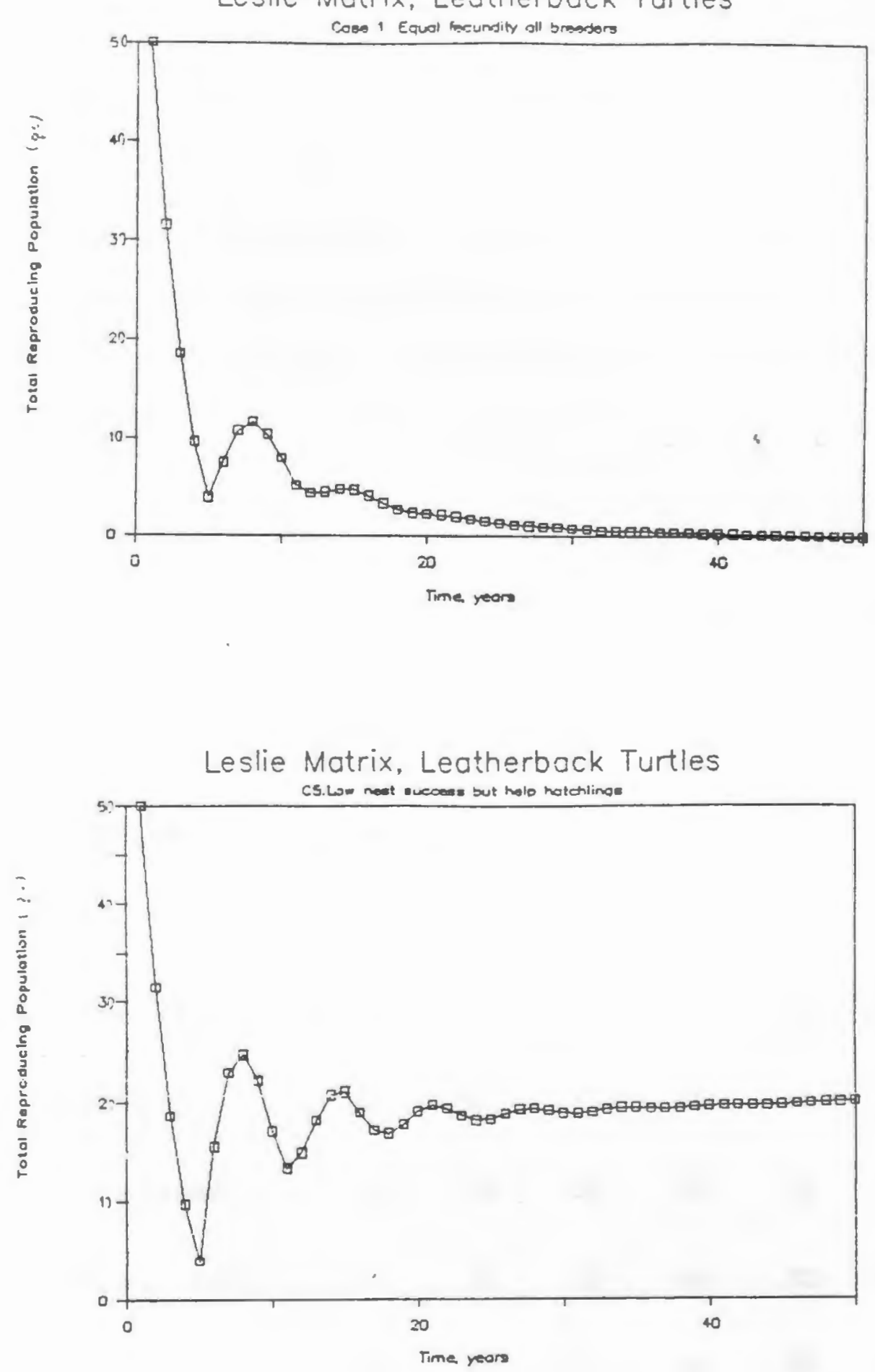

Figure 3. A comparison of simulated population trends, first (A) using hypothetical survivorship estimates given in Table 2; then modified ( $B$ ) to increase juvenile survivorsh1p by $10 \%$ and decrease egg survivorship by $25 \%$. 
Table 2. Survivorship values for leatherback turtle stage classes used in the Leslie matrix simulations and resultant eigenvalue (lambda) values. A lambda of less than one indicates eventual extinction.

Stage clase Stage-specific survivorsh1ps

\begin{tabular}{|c|c|c|c|c|c|c|c|}
\hline$P[0]$ & egga & .85 & .85 & .85 & .60 & .85 & .85 \\
\hline$P[1]$ & emergent hatchlinga & .05 & .05 & .15 & .15 & .15 & .05 \\
\hline$P[2]$ & young juventles & .10 & .10 & .10 & .10 & .10 & .10 \\
\hline$P[3]$ & older juveniles & .15 & .15 & .15 & .10 & .10 & .10 \\
\hline$P[4]$ & neophyte breeders & .90 & .90 & .90 & .90 & .90 & .99 \\
\hline$P[5]$ & remigrant & .80 & .50 & .50 & .80 & .50 & .99 \\
\hline$P[6]$ & 3rd time breeder & .70 & .50 & .50 & .70 & .50 & .99 \\
\hline$P[7]$ & 4th tine breeder & .60 & .50 & .50 & .60 & .50 & .99 \\
\hline$P[8]$ & Sth tiwe breeder & .50 & .50 & .50 & .50 & .50 & .99 \\
\hline
\end{tabular}

Approximate $\begin{array}{lllllll}\text { elgenvalues }(\lambda) & .894 & .854 & 1.02 & 1.00 & .964 & .948\end{array}$ 
reproductive waturity. If, hovever, a faster grovth rate of only 3 years to maturity is used (as suggested by Rhodin (1985)), the transition probabilty for stage to stage survivorship must be altered. If this is done, the results reveal that the hatchling sector is most critical in promoting population increase.

Population simulations are sensitive to errors in párameter estimation, and can generate misleading conclusions. Some parameters are more critical than others; in these simulations, age at maturity and related transition probabilities are extremely critical parameters. If these models are used to justify management, incorrect estimates of survivorship probabilities could lead to disasterous managament. One could develop a set of demographic scenarios for differing grovth and development rates and then vait for more definitive information on grovth to be obtained, but all vill be for naught if length of reproductive period of breeding adults remain unknovn. Consequently, the major thrust of research efforts should be focused on these aspects of sea turtle biology. Deriving further demographic information on leatherback and other sea turtle species 18 critical now; without it conservationists and managers of sea turtle populations cannot gauge the success of their work. 


\section{MANAGEMENT IMPLICATIONS OF LEATHERBACK TURTLE DEMOGRAPHY}

The most obvious implication of the preceding discussion is that further study of sea turtle demographics is desperately needed and is a prerequisite to effective management. Hovever, there are some important messages contained in the demographic information already accruing. First, the non-contiguous nature of the Atlantic population of leatherback turtles casts doubt on the usefulness of treating the North Atlantic leatherback population as a single entity. Each population unit or deme must be managed independently for recovery. If, conversely, the results of the genetic analysis had provided evidence for a panmictic Atlantic population, then managers responsible for the recovery of leatherbacks could set priorities for management areas - and efforts to preaerve a relatively minor nesting group such as the Virgin Island population might be discouraged in favor of a better investment elsevhere.

But independent demes do exist in the structure of the North Atlantic leatherback turtle population. Each stock has a unique genetic composition, therefore each gene pool should be conserved, because the genetic character of a population group determines how vell that population 111 be able to adapt to change over evolutionary time. Considering the possibly small demic sizes, genetic drift 18 a serious possibility. We have no idea what the adaptive landscape, as expressed by the Wright (1969), w111 present to future leatherback generations in the form of evolutionary challenges. A high degree of heterozygosity vithin the species or 
vithin a geographical subgroup as a wole will help probably allov an adequate evolutionary response to change. If, through ignorance or misdirected management, small and seemingly insignificant demes become extinct, the genetic variability of the species and its ability to cope with environmental change may be undermined.

Perhaps the logical conclusion is that all sub-populations in the Atlantic region should be managed with equal effort. Hovever, there are complicating factors generated by this newly documented picture of stock structure. If the North Atlantic population is indeed fragmented into discrete demes that roughly correspond to nesting groups, then perhaps some sub-populations must be closer to minimum viable population sizes than assumed. The Virgin Island nesting population, probably comprised of fever than 100 breeding females, may belong to a deme of less than 200 adults, assuming an equal sex ratio. If one believes the minimum effective population size Rule of 500 (Franklin, 1980), then this deme may be in grave danger of slipping belor threshold levels. The situation is made even more critical if one assumes a sex ratio of males to females of less than one and males are not polygamous, or when adult recruitment from a dvindling juvenile population is decreasing.

The logical counterargument is that there is no reason to believe the Virgin Islands stock is near the minimum viable population size, since the population numbers appear to be stable over the short term of seven years (Eckert and Eckert, 1985). Possibly, the deme is comprised of individuals making up the Virgin Islands, Culebra, and possibly the Dominican Republic breeding groups together. Again, the desperate need for further genetic and 
demographic studies is emphasized. But one point remains clear: the further fragmenting of an already small population such as the deme outlined above could bring 1 ts subgroups precariously near minimum effective population size and thus potential population collapse.

Simulations performed to study hor the rate of replacement varies with changing life table parameters may elicit further caution. If the older juvenile sector is the most important in maintaining or increasing population size (Crouse, 1985), then management measures augmenting survivorship of population subgroups, especially of those populations near minimum viable population size, should be implemented. No conservation activities have been deliberately undertaken to protect leatherback turtles of the larger juvenile and nevly mature age groups. Even Turtle Excluder Device (TED) regulations aimed at reducing mortality of sea turtles caught incidentally in shrimp fishing operations vill not signficantly increase survivorship of leatherbacks, since only rarely do fishing operations in the Gulf of Mexico and Southeast U.S. impact leatherback turtles.

At present, enormous quantities of money, coming from both governmental agencies and private foundations, are spent to conserve the earliest age group of sea turtles: eggs and emergent hatchlings. This potentially constitutes a poor choice in allocation of funds. Hovever, the positive outcome of this investment has been to increase both public avareness and interest in sea turtles, which may in turn to increased funding opportunities for better protection.

I know of no data wich confirm any specific age class of 
Dermochelye coriacea as being most sensitive in altering the rate of population increase. Hovever, there is anecdotal evidence suggesting the mature age classes are more critical than the egg stage of development. On the Caribbean coast of Costa Rica, a 25 kilometer nesting beach between Puerto Limon and Tortuguero, is heavily used by nesting leatherbacks. Egg poaching in this area has occurred at a sustained high rate for many years. My intervievs with members of the local communities reveal that this practice goes back many generations, and 18 an integral component of the culture of inhabitants. Many young poachers conceded that they learned their trade from a parent or grandparent. During the nesting season, scarcely a nest is left in the sand. Hov, then, is this population able to sustain itself?

One answer, wich 18 purely speculative, is that leatherbacks have evolved their highly fecund reproductive patterns to sustain a high natural mortality of egge and hatchlings. Prior to coastal settlement in these areas, human predation of eggs ras not in the ecological equation for leatherbacks. Hovever, humans in some areas now displace natural predators, including jaguars, seabirds, and coatimundis, in competition for sea turtle eggs. The rates of this human predation have probably increased steadily over the decades of settlement in the area. Leatherbacks may have an adaptive strategy that ensures that at least some clutches will survive to hatching: the apparently unpredictable timing of the onset of nesting. Since villagers said they vere unavare that turtles vere nesting on their beaches until the season vas vell undervay, many early clutches (and probably the last clutches) vere missed and thus may have survived to 
hatching.

If some nests are successful, why then are the leatherback populations declining? One ansver may be because adult mortality, once extremely low due to the absence of natural predators on adults, may be increasing. More and more large immature and adult leatherbacks are becoming entangled in fishing gear ( $R$." Prescott, pers. comm.) and more may be dying from ingesting plastic and other debris (Balasz, 1985). Perhaps, from a population dynamica perspective, high egg losg is lese detrimental than high adult mortality. Such a situation vould confirm Pritchard's (1980) comment "I am atill convinced that those Individuals that have survived the vicisitudes of their long pre-maturity period, namely the breeders, are the most important to protect". 


\section{CONCLUSIONS}

It has not been my intention to claim that the collective scientific efforts of sea turtle biologists and conservationists have been consclously misguided when it comes to providing the necessary information for the management of Dermochelys coriacea. Nor have I meant to belittle the efforts of the myriad of groups vorking to save this species from extinction. Beach patrols, the guarding of eggs and young, translocations of eggs, and other common conservation practices cannot be considered counterproductive, even if their end result is a negligible increase in population size and incrementally minor additions to our state of knovledge. But program administrators and management agencies should be aware that their conservation efforts will not be efficient, either with respect to time or finances, unless further demographic information on Dermochelys is obtained promptly. I believe consideration should be given to the strong possibility that the significant effort and money needed to run costly programs with unknown returns on investment, such as head-starting projects for many sea turtle species where hatchlings are reared a year or more prior to release, should be reallocated to studies which further elucidate stock structure, growth curves, and life history parameters. With limited resources to undertake both scientific study and conservation, and an already short time horizon that is foreshortened vith every passing day, we must work hard at being efficient. 


\section{ACKNOWLEDGEMENTS}

I thank Nat Frazer and Deborah Crouse for sharing their Ideas about the 1mportance of sea turtle demography work, and Brooks Martin vho so gallantly came to my rescue vhen I struggled with the population simulations. Thanks also to Karen Eckert, who ran the Earthwatch-sponsored program in St. Croix vith great enthusiasm and dedication, who remained supportive throughout wy study, and who continues to be an inspiration. Special thanks are in order to Saul Salla and Robert Shoop, who convinced me despite my Hungarian biases that hard vork is not only necessary but also fun. This vork was supported in part by the Pev Charitable Trusts and the Marine Policy Center of the Woods Hole Oceanographic Institution. 


\section{LITERATURE CITED}

Agardy, M.T. 1989a. Genetic variability in tro seasonally allopatric populations of the leatherback turtle, Dermochelys coriacea. Ph.D. Dissertation manuscript, University of Rhode Island.

Agardy, M.T. 1989b. A note on an easy and effective method to obtain blood samples from sea turtles. Ph. D. Dissertation manuscript, University of Rhode Island.

Avise, J. 1987. Identification and interpretation of mitochondrial DNA in marine species. In Proceedings of the Stock Identification Workshop, 5-7 Nov 1985. NOAA-TM-NMFS-SEFC- 199:105-136.

Balasz, G.H. 1985. Impact of ocean debris on marine turtles: entanglement and ingestion. pp 387-429 In R. S. Shomura and H.O. Yoshida, eds. Proceedings of the Workshop on the Fate and Impact of Marine Debris, 26-29 Nov 1984. MOAA-TM-NMFS-SWFC- 54.

Bjorndal, K.A. 1980. Demography of the breeding population of the green turtle, Chelonia mydas, at Tortuguero, Costa Rica. Copeia $1980(3): 525-530$.

Boven, B., A. Meylan, and J. Avise. 1989. An odyssey of the green turtle, Ascension Island revsisited. Proc. Natl. Acad. Sc1. (USA) 86: 573.

Brongersma, L. D. 1972. European Atlantic turtles. Zool. Verhandl. $121: 1-318$. 
Bustard, H.R. 1972. The leathery turtle. Oryx 11(4): 233-234.

Carr, A.F. 1952. A Handbook of Turtles. Cornell University Press: Ithaca, NY.

Carr, A.F. 1971. Research and conservation problems in Costa Rica. Proceedings of the Second Working Meeting of Marine Turtle Specialists, Morges, Switzerland, 8-10 Mar. 1971. IUCN Publication: 29-33.

Carr, A.F. 1987. Impact of nondegradable marine debris on the ecology and survival outlook of sea turtles. Mar. Poll. Bull. $18(6): 352-356$.

Crouse, D.T. 1985. The biology and conservation of sea turtles in North Carolina. Ph. D. Dissertation, U. Wisc., Madison.

Crouse, D.T., L. B. Crovder, and H. Casvell. 1987. A stage-based population model for loggerhead sea turtles and implications for conservation. Ecology $68(5)$ : 1412-1423.

Deraniyagala, P.E.P. 1939. The tetrapod reptiles of Ceylon. Vol I. Tegtudines and Crocodilians. Columbo Mus. Nat. Hist. Ser. Columbo, Ceylon (Sri Lanka): 412 pp.

Eckert, K. L. and S.A. Eckert. 1985. Tagging and nesting research of leatherback sea turtles (Dermochelys coriacea) on Sandy Point, St. Cro1x, 1985. Ann. Rep. U.S. Fish Wildl. Ser. MIN54-8680431. 
Eckert, K. L. and S.A. Eckert. 1988. Pre-reproductive movements of leatherback sea turtles (Dermochelys coriacea) nesting in the Caribbean. Copeia 1988 (2): 400-406.

Eckert, S.A., D.W. Nellis, K. A. Eckert, and G. L. Kooyman. 1986. Diving patterns of two leatherback turtles (Dermochelys coriacea) during internesting intervals at Sandy Point, St. Croix. Herpetologica 42: $381-388$.

Fitter, R.S. 1961. The leathery turtle or luth. Oryx 6: 116-125.

Franklin, I.A. 1980. Evolutionary change in small populations. pp 135-150. In M. Soule and B. Wilcox [eds]. Conservation Biology: An Evolutionary Approach. Sinauer Assoc., Sunderland, MA.

Frazer, N.B. 1983. Demography and life history evolution of the Atlantic loggerhead sea turtle, Caretta caretta. Ph. D. Dissertation, U. Georgia, Athens.

Frazier, J. 1987. Semantics and the leathery turtle, Dermochelys coriacea. J. Herp. $21(3): 240-242$.

Fretey, J. and J. Lescure. 1979. Rapport sur 1'etude de la protection des tortues marines en Guyane Francaise. Notes sur le projet de reserve naturelle de Basse Mana a Ministere de la Culture et de L'Environnement Direction de la Nature, Paris.

Fritts, T.H., W. Hoffman, and M.A. McGehee. 1983. The distribution and abundance of marine turtles in the Gulf of Mexico and nearby Atlantic vaters. J. Herpet. 17: 327-344. 
Goff, G.P. and J. Lien. 1988. Leatherback turtles (Dermochelys coriacea) in cold waters of Nevfoundland and Labrador. Can. Field Nat. $102(1): 1-5$.

Gorman, G.C. and J. Renzi, Jr. 1979. Genetic distance and neterozygosity estimates in electrophoretic studies: effects of sample size. Copeia 1979(2): 242-249.

Greer, A.E., J.D. Lazell and R.M. Wright. 1973. Anatomical evidence for a counter-current heat exchanger in the leatherback turtle (Dermocehlys coriacea). Nature 244: 181.

Groombridge, B. 1982. The IUCN Amphibia-Reptilia Red Data Book: Part 1: Testudines, Crocodilia, and Rynchocephalia. IUCK. Gland, Switzerland.

Hirth, H. and L. Ogren. 1987. Some aspects of the ecology of the leatherback turtle, Dermochelys coriacea, at Laguna Jalova, Costa Rica. NOAA Tech. Rep. 56.

Laist, D.W. 1987. Overview of the biological effects of lost and discarded plastic debris in the marine environment. Mar. Poll. Bull. $18(6): 319-326$.

Lande, R. 1988. Genetics and demography in biological conservation. Science 242: 1455-1460.

Lazell, J.D., Jr. 1980. New England waters: critical habitat for marine turtles. Copeia $1980(2):$ 290-295. 
Meylan, A., P. Meylan, and A. Ruiz. 1985. Nesting of Dermochelys coriacea in Caribbean Panama. J. Herp. 19(2): 293-297.

Pritchard, P.C.H. 1971. The leatherback or leathery turtle, Dermochelys coriacea. IUCN Monograph 1: 1-39.

Pritchard, P.C.H. 1976. Post-nesting movements of marine turtles (Cheloniidae and Dermochelyidae) tagged in the Guianas. Copeia $1976(4): 749-754$.

Pritchard, P.C.H. 1980. The conservation of sea turtles: practices and problems. Amer. Zool. 20: 609-617.

Pritchard, P.C.H. 1982. Nesting of the leatherback turtle, Dermochelys coriacea, in Pacific Mexico, with a new estimate of the vorld population status. Copeia 1982(4): 741-747.

Rhodin, A.G. 1985. Comparative chondro-osseus development and growth of marine turtles. Copeia 1985: 752-771.

Ross, J.P. 1982. Historical decline of loggerhead, ridley, and leatherback sea turtles. pp189-209 In K. A. Bjorndal [ed.], Biology and Conservation of Sea Turtles. Smithsonian Inst. Press: Washington, D.C.

Ross, J.P. and J.P. Ottenvalder. 1983. The leatherback turtle, Dermochelys coriacea, nesting in the Dominican Republic. pp 706713 In A. Rhodin and K. Miyata [eds.]. Advances in Herpetology and Evolutionary Biology. Museum of Comparative Zoology, Cambridge, MA. 
Salla, S. and B.K. Martin. 1987. A brief review and guide to multivariate methods for stock Identification. Proceedings of the Stock Identification Workshop, 5-7 Nov 1985, Panama City Beach, Fla. NOAA Tech. Mem. NHFS SEFC 199: 149-174.

Shoop, C.R. 1980. Inuit turtle song: leatherback turtles near Baffin Island. Marine Turtle Mersletter 15: 5-6

Shoop, C.R. 1987. Sea turtles. In R. Backus and H. Bourne, [eds. ], Georges Bank. MIT Press, Cambridge, MA.

Shoop, C.R., T.L. Doty, and N.E. Bray. 1981. Sea turtles in the region between Cape Hatteras and Nova Scotia in 1979. pp IX: 2-89 In: A characterization of marine mamals and turtles in the midand North Atlantic areas of the U.S. Outer Continental Shelf. Annual Rep. for 1979. CETAP. Kingston, RI.

Standora, E. A., J.R. Spotila, J.A. Keinath, and C.R. Shoop. 1984. Body temperatures, diving cycles, and movement of a subadult leatherback turtle. Herpetologica 40: 169-176.

Thompson, N.B. 1980. Population dynamics of the Atlantic green sea turtle, Chelonia mydas, (Linnaeus) 1758. Ph. D. Diseertation, University of Rhode Island, Kingston, RI.

Thompson, T.J. and C.R. Shoop. 1983. Southeast turtle survey (SETS), pelagic surveys. Final report to MMFS. Aero-Marine Surveys Inc. Groton, CT. 76pp. 
Whitmore, C.P. and P.H. Dutton. 1985. Infertility, embryonic mortality, and nest site selection in leatherback and green sea turtles in Suriname. Biol. Cons. 34: 251-272.

Wright, S. 1969. Evolution and the Genetics of Populations. Yol. II. U. Chicago Press, Chicago, Ill. 
APPENDIX A : STAIMING REACTIONS FOR IEF GELS 
APPENDIX A: Staining reactions for Iso-electric focusing gels.

The data from this investigation come from tro distinct methodologies used to decipher population differences between tro geographically distinct nesting groups of leatherback sea turtles. The null hypothesis tested vas the same in both investigations: that the tro subgroups sampled exhibit no group differences with respect to electrophoretically detectable characteristics. Both methodologies vere used on single bood samples taken from each sea turtle.

The first data set (Table 1, Manuscript 1) described whether a particular enzyme variant vas present in the blood sample. All sea turtle blood contains the common enzymes needed for metabolism, but genetic variants of these enzymes (allozymes) differ from individual to individual. These allozymes are functionally identical but structurally different in iso-electric point (the $\mathrm{pH}$ at which the molecule is electrostatically neutral). Staining the gel with an electron-transfer dye wich detects a particular enzyme (and in fact uses that enzyme in the chain reaction needed for staining) results in visual detection of all allozymes present in the sample. The staining reactions for each enzyme investigated are given on the following pages (Figures 1 and 2). The binary data thus correspond to the presence or absence of a particular allozyme as detected through use of an iso-electric focusing apparatus and subsequent staining. 
The second data set (Table 3, Manuscript 1) revealed the total protein complement present in the same blood samples. Using this method, the researcher stains the sample for all proteins, rather than for a specific metabolic enzyme. The gel banding patterns are read by a Bcanning integrated transmission densitometer. The value representing each protein band is an estimate of the areal extent of the band as it sits on the gel. These rav densitometry data vere then arc-sine transformed and compiled for discriminant analysis, according to the methods of Fabrizio (1986). 
LDH

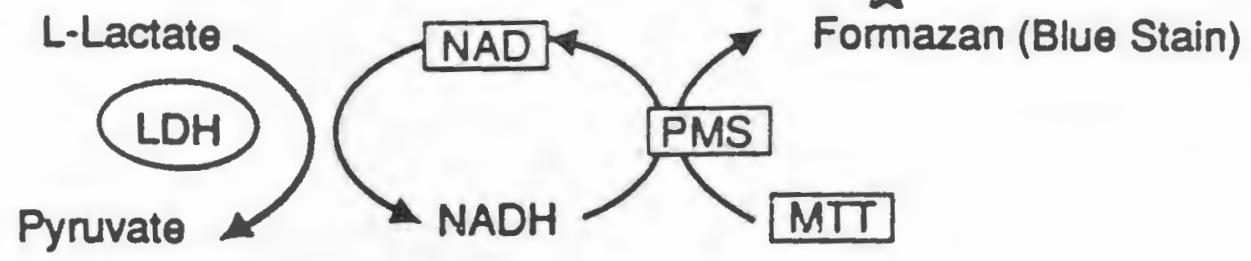

\section{PGM}

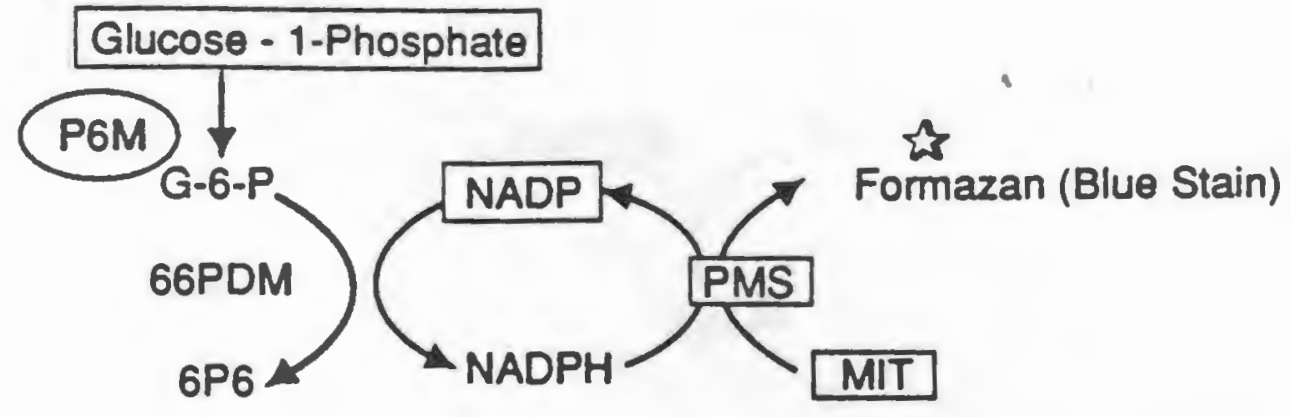

6-PGD

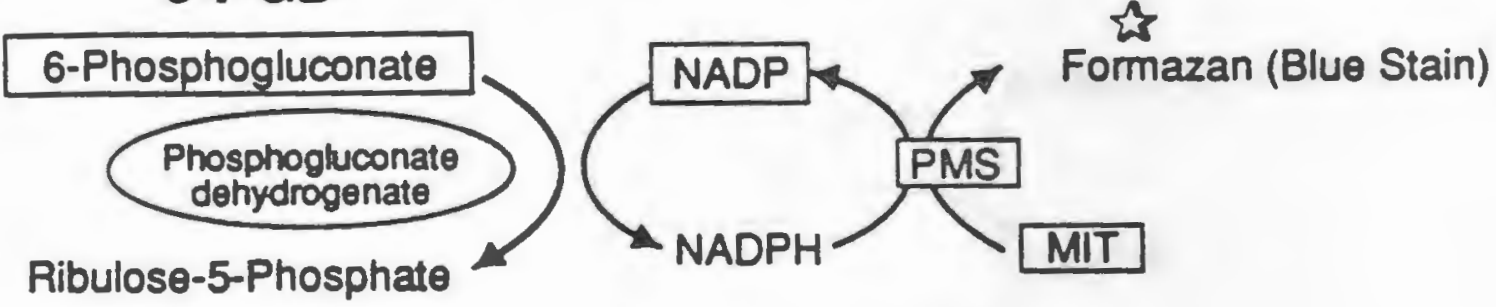

\section{PEP}

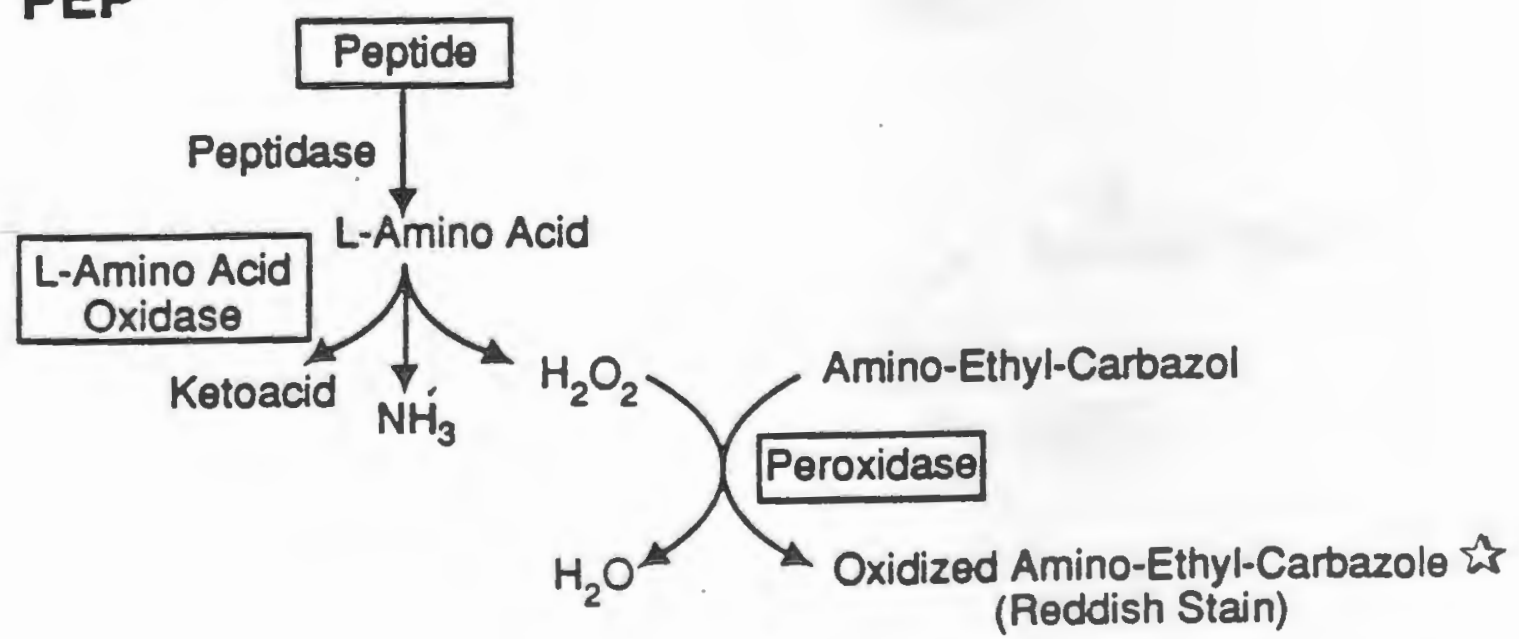

Figure 1. Staining reactions for $L D H, P G K, 6-P G D$, and PEP 
EST

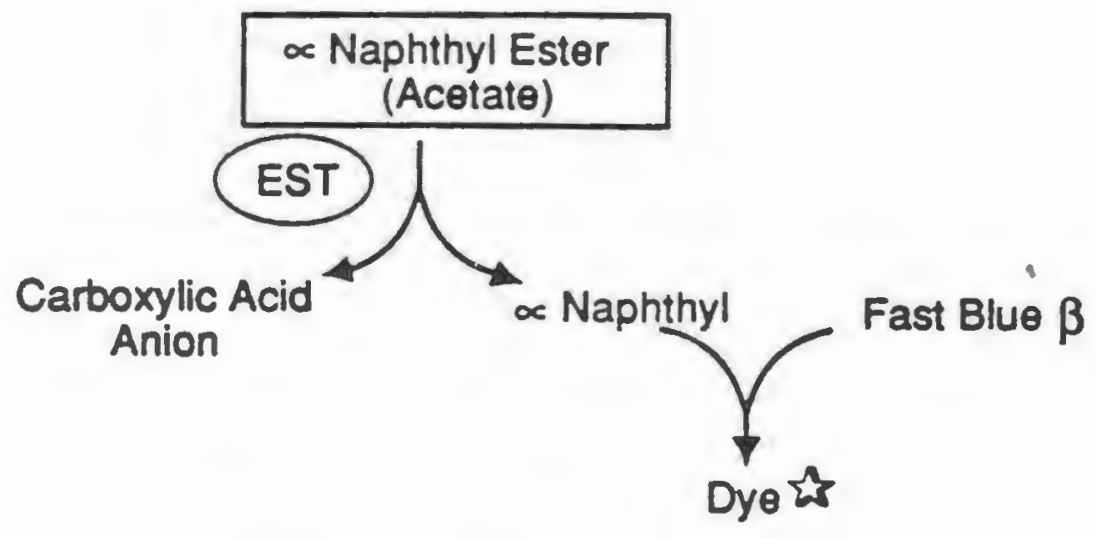

HK

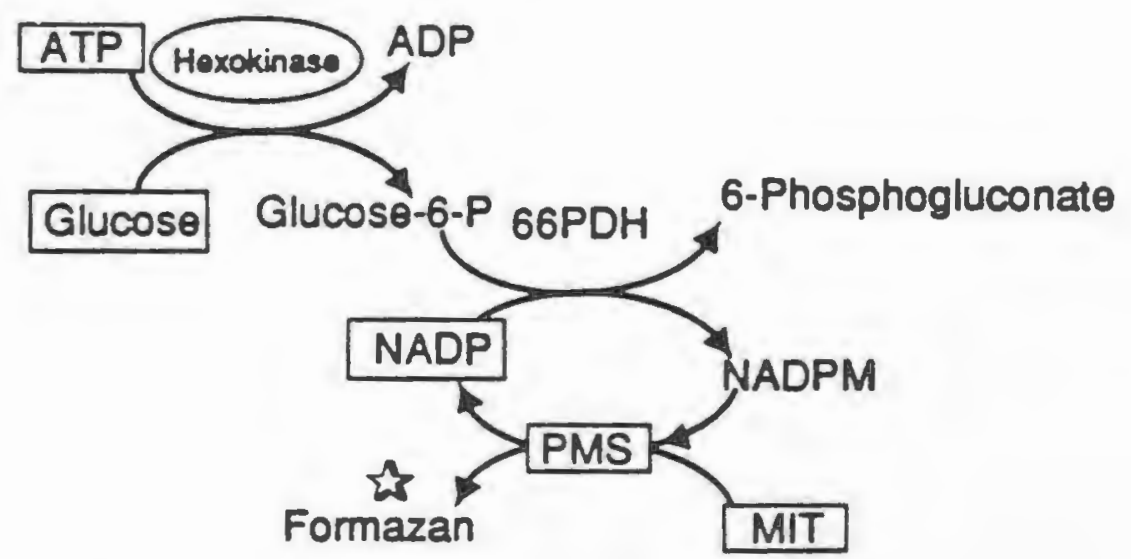

GAPDH

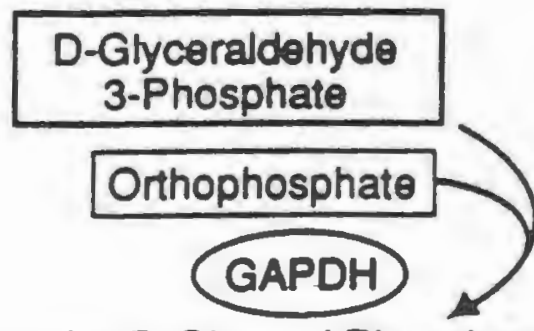

3-Phospho-D-Glycerol Phosphate

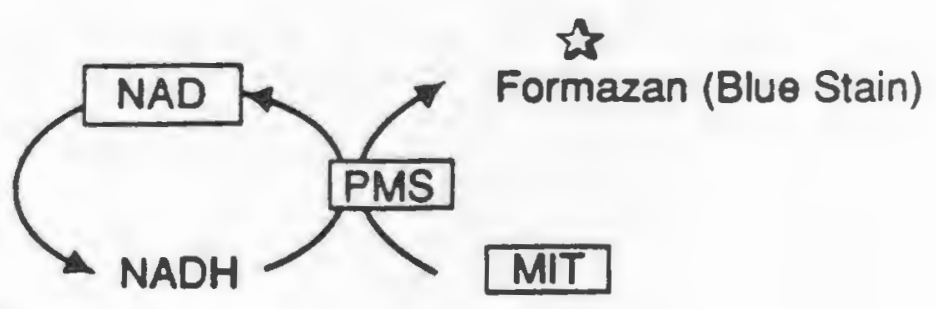

Figure 2. Staining reactions for EST, HK, and GAPD 
APPENDIX B: LESLIE MATRIX SIMULATIONS 
APPENDIX B.

\section{LESLIE MATRIX SIMULATIONS OF A DERMOCHELYS CORIACEA POPULATION USING HYPOTHETICALLY-DERIVED PARAKETERS}

\section{INTRODUCTION}

Knovledge of demographic trends is critical to understanding how vell and how quickly stressed populations can be expected to recover given certain management measures. The value of such demographic information was brought to light in Cole's (1954) landmark paper, but has been overshadoved by the recent use of population genetics as a management tool (Lande, 1988). Fev researchers have studied the population dynamics of sea turtles, with the notable exceptions of Bjorndal (1980), Crouse (1985) and Frazer (1983), although most studies contribute in some vay to better understanding of life history parameters. Without this information, only crude estimates of population dynamics can be made and the recovery potential of any population cannot be determined.

In order to investigate the vay in wich life history estimates influence predictions of an endangered population's recovery potential, I ran several simulation exercises using a Leslie matrix model. Once again, these simulations require some knowledge about the demography of the species; in cases such as this one vhere the demographic parameters are unknown, they must be estimated using the best available information. The age at first reproduction, total life 
span, reproductive life span, frequency of reproduction, and mortality rates for all life stages beyond the egg stage, are not known for Dermochelye coriacea. With the exception of fecundity and nest (hatching) success, virtually all the demographic parameters must be hypothesized. Some of these approximations can be inferred from better data that exist for vild green (Chelonia aydas) and loggerhead (Caretta caretta) sea turtles (e.g. Bjorndal, 1980; Crouse, 1985; Crouse et al., 1987; and Frazer, 1983; ) and captive-reared individuals of these tro species. Hovever, Dermochelys coriacea is markedly different from these other sea turtle species in anatomy (Greer et al., 1973; Rhodin, 1985), physiology (Eckert et al., 1986; Standora et al., 1984), and behavior (Eckert and Eckert, 1988; Lazel1, 1980; Pritchard, 1982) so such extrapolations may not be valid.

Despite these qualifications, leatherback turtle population modeling can lead to at least three important findings: 1) an indication of potential population recovery times given management regimes protecting certain age classes, 2) an assessment of the senstivity of demographic parameters to changes in value, such that the most critical life history stages can be targetted for managenent to result in the speediest recovery, and 3 ) an indication of vhere more data on demographic parameters are most needed. 
A Leslie matrix model (Leslie, 1945) vas used to simulate demographic trends in a hypothetical leatherback turtle nesting population comprised of one hundred adults, of which 50 are breeding females. Since the life history stages of sea turtles (e.g. eggs, hatchlings, sub-adult, breeding adult) are of unequal duration, the model chosen is one with a stage- rather than age-class structure (Vandermeer, 1975). This stage-class model has also been used in modeling loggerhead turtle populations with interesting results (Crouse et al., 1987). According to the model, the number of individuals in any stage class in the year $t+1$ is a function of the number of individuals in that year class in the year $t$ such that

$$
A x(t)=x(t+1)
$$

where $x(t)$ is a vector of stage classes at time $t$ and $A$ is a square matrixof the form:

$$
\begin{aligned}
& \begin{array}{lcccccc}
g(0) & g(1) & . & . & g(m-1) & g(m) \\
g(0) & 0 & . & . & 0 & 0
\end{array} \\
& A=\quad \begin{array}{lll}
a & a(1) . \ldots .
\end{array}
\end{aligned}
$$

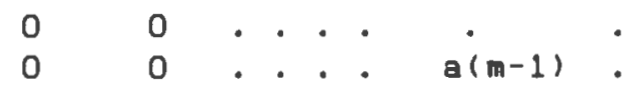

Where $g(x)$ is the number of offspring in each stage class that survive that period and $a(g x)$ is the transition probability describing the number of individuals of one stage class that survive to enter the next.

A paucity of data on mortality of leatherbacks of all ages makes it impossible to generate population models of the species vithout arbitrarily assigning parameter values. The values used in this study 
are based on existing information for loggerhead turtles, with

necessary amendments based on wat little ve do knor about leatherback life histories. The life history parameters used in the model are the following:

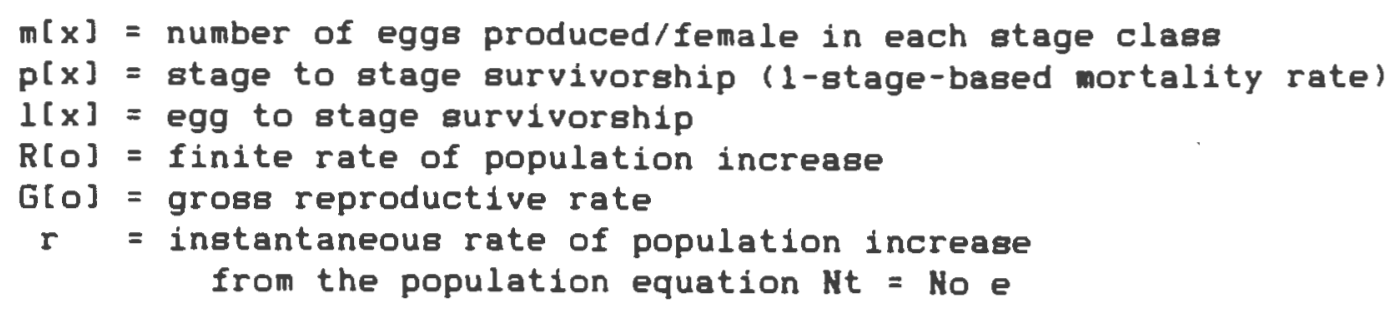

The five life history stages used in the model are:

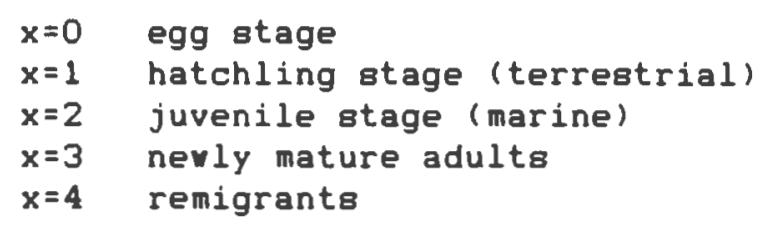

The only values for wich ve have definitive information are $m[x]$, $l[x]$, and the duration of the $x=0$ life stage; these values come from my own vork with leatherback turtles and from published sources. All other parameters must be estimated through extrapolation from other apecies. One assumption that must be made to ensure that the Leslie matrix model, which deciphers population trends for females members of a population only, 18 realistic is a one to one sex ratio among adults (Stancyck, 1982). No information about sex ratios of leatherbacks exists in the literature, hovever equal sex ratios have been assumed in investigations of other sea turtle species (Frazer, 1983; Ros8, 1982). Other possibly unrealistic assumptions are that the population is closed (alloving no consideration for emigration or immigration), and that density dependent mortality effects do not exist.

The Leslie matrix model is a deterministic model which follows the female population through time to simulate trends in total 
population size. The elements of the matrix include age-specific fecundity in Rov 1 and age-specific survival probabilities in the subdiagonals. Vectors built from observed (or in this case hypothesized) data allow matrix multiplications wich result in the dominant latent root or eigenvalue. If this value is one, the population can be considered at equilibrium; if less than one the population vill decrease; and if greater than one the population vill increase.

The specific kinds of data that are needed and should be verified by time-series observation are:

1) the number of eggs produced by every stage class;

2) the mortality rates for each stage class from the start to the end of each time period, from wich survival estimates are inferred;

3) the total number of size or stage classes vithin the matrix;

4) adult sex ratio;

5) the number of remigrants and new recruits to nesting for each time interval.

Using hypothesized values for the life history of the leatherback (Ms. 1, Table 1), a life history table can be constructed for use in a Leslie matrix that simulates population sizes over time for any initial vector. A deterministic Leslie matrix model designed for a LOTUS 1-2-3 software program, designed by B. Martin, was used for the manipulations. The first matrix used in the simulation exercise ras the following, based on an simplified version of the hypothetical life history table (Table 1):

$\begin{array}{ccccc}0 & 0 & 0 & 220 & 220 \\ .85 & 0 & 0 & 0 & 0 \\ 0 & .217 & 0 & 0 & 0 \\ 0 & 0 & .03 & 0 & 0 \\ 0 & 0 & 0 & .01 & 0\end{array}$


Using a total adult population size of 2000 individuals, of which 1000 are females, an arbitrary initial vector vas used to run the simulations.

After 50 years, the matrix manipulation yielded a dominant eigenvalue, $\lambda[\mathrm{m}]$, of 0.896 , indicating that the population 18 declining at an annual rate of -0.014 .

For the second set of simulations, the matrix ras expanded to include five breeding cycles. Stage classes vere used as above, but hatchlings vere divided into those on land and those at sea, and a juvenile (labeled subadult in the data printouts) stage class vas added. In addition, breeding females vere divided into nevly mature (neophyte breeders), 2nd time breeders or remigrants, 3rd time breeders or remigrants, 4th time breeders or remigrants, and 5th time breeders or remigrants. The model vas also expanded to run for a 200 , rather than a 50, year simulation.

Using a conservative estimate of survivorship probabilties as follove:

$\begin{array}{lcc}\text { stage class } & \text { survivorship } & \text { fecundity } \\ \text { eggs } & .85 & 0 \\ \text { hatchlings(land) } & .05 & 0 \\ \text { hatchlings(marine) } & .10 & 0 \\ \text { juvenile } & .15 & 0 \\ \text { neophyte } & .90 & 220 \\ \text { 2nd time breeder } & .80 & 220 \\ \text { 3rd time breeder } & .70 & 220 \\ \text { 4th time breeder } & .60 & 220 \\ \text { 5th time breeder } & .50 & 220\end{array}$


an eigenvalue approximation of 0.894 resulted. This simulation assumes an equal average fecundity for all breeding females; if the fecundity is reduced so that 4 th and 5 th $t i m e$ breeders do not produce viable eggs, the eigenvalue approximation drops slightly to 0.845 (see appended data sheets).

A significant change occurs if hatchling or fuvenile survivorship is increased even slightly. If, for instance, hatchling survivorship is increased just $10 \%$, from .05 to .15 , the population simulation shovs an increasing population over 200 years. Even when the egg survivorship is reduced by $25 \%$ whlle the hatchling survivorship is maintained at the .15 value, an eigenvalue approximation of 1.003 Indicates an increasing population (see Figure 1).

Various scenarios using different survivorship values and fecundity parameters vere run. The most interesting combinations are given in Table 1, with corresponding eigenvalues. The conclusion from these simulations is that vile variability in egg survivorship only slightly changes population projections, manipulating the juvenile parameters significantly alters the demographic trends. The neophyte breeder survivorship is also an important parameter. Thus, the most sensitive variables are the sub-adult stage survivorships.

The implications of the matrix simulation are trofold: first, ve may do vell to rethink our management and conservation efforts to focus more on the most sensitive age classes (juveniles and nevly mature adults); and second, that further basic research is needed to better define demographic parameters. Until ve knov, or at least have observation-based estimates of, stage class mortalities and grovth 
rates, ve cannot begin to have an accurate understanding of leatherback turtle population dynamics. And vithout this understanding, sea turtle management will continue to capitalize on opportunity rather than on wat is most effective.

\section{ACKNOWLEDGMENTS}

Brooks Martin of U.R.I. developed the LOTUS 1-2-3 Leslie matrix program \& vas invaluable in assisting with the simulations.

\section{LITERATURE CITED}

(See disвertation bibliography) 


\section{BIBLIOGRAPHY}

Agardy, M.T. 1981. Preliminary report on the reproductive success of leatherback turtles at Sandy Point, St. Croix. Unpublished U.S. Fish and Wildlife Service Report. Atlanta, GA.

Agardy, M. T. 1988. Biology and conservation of sea turtles nesting in Quintana Roo, Mexico, 1988. Report to the U.S. Fish and Wildlife Service, Albuquerque, N. M.

Allendorf, F. and R. Leary. 1986. Heterozygosity and fitness in natural populations of animals. pp 57-76 In M. Soule, [ed.] Conservation Biology. Sinauer, Sunderland, MA.

Avise, J. 1987. Identification and interpretation of mitochondrial DNA in marine species. Proceedings of the Stock Identification WorkBhop, 5-7 Nov 1985. NOAA-TM-NMFS-SEFC-199: 105-136.

Bacon, P., F. Berry, K. Bjorndal, H. Hirth, L. Ogren, and M. Weber, [eds.]. 1984. Proceedings of the Western Atlantic Turtle Symposium. Univ. Miami Press, Miami.

Baker, G. 1980. Recovery plan: leatherback turtle (Dermochelys coriacea). U.S. Fish and Wildlife Service unpublished document.

Balasingham, E. 1967. The ecology and conservation of the leathery turtle Dermochelys coriacea in Malaya. Micronesia 3: 37-43. 
Balasz, G.H. 1985. Impact of ocean debris on marine turtles: entanglement and ingestion. pp 387-429 In R.S. Shomura and H. O. Yoshida. [eds.] Proceedings of the Workshop on the Fate and Impact of Marine DebriB, 26-29 Nov 1984. NOAA-TM-NMFS-SWFC54.

Bels, V., F. Rimblot-Baly and J. Lescure. 1998. Croissance et maintien en captivite de la Tortue Luth Dermochelys coriacea (Vandelli, 1761). Revue fr. Aquariol. 15.: 59-64.

Berkson, H. 1966. Physiological adjustments to prolonged diving in the Pacific green turtle (Chelonia mydas agassizii). Comp. Biochem. Physiol. 18: 101-119.

Bjorndal, K.A. 1980. Demography of the breeding population of the green turtle, Chelonia mydas, at Tortuguero, Costa Rica. Copeia $1980(3): 525-530$.

Boven, B., A. Meylan, and J. Avise. 1989. An odyseey of the green turtle: Ascension Island revisited. Proc. Matl. Acad. Sci. (USA) B6: 573.

Brongersma, L. D. 1972. European Atlantic turtles. Zool. Verhandl. Leiden 121: 1-318.

Brovn, B.E., G.H. Darcy, and W. Overholtz. 1987. Stock assessment / stock identification: an interactive process. Proceedings of the Stock Identification Workshop, 5-7 Nov. 1985, Panama City Beach, Fla. NOAA Tech. Mem MMFS-SEFC-199: 1-24. 
Bustard, H.R. 1972. The leathery turtle. Oryx 11(4): 233-234.

Carr, A.F. 1952. Handbook of Turtles. Cornell University Press: Ithaca, NY.

Carr, A.F. 1971. Research and conservation problems in Costa Rica. Proceedinge of the Second Working Meeting of Marine Turtle Specialist8, Morges, Svitzerland, 8-10 Mar 1971. IUCN Publ. I : $29-33$

Carr, A.F. 1987. Impact of nondegradable marine debris on the ecology and survival outlook of sea turtles. Mar. Poll. Bull. $18(6): 352-356$.

Carr, A.F. and L. Ogren. 1959. The ecology and migrations of sea turtles, 3. Dermochelys in Costa Rica. Am Mus. Mov. 1958: 1-29.

Cole, L.C. 1954. The population consequences of life history phenomena. Quart. Rev. Biol. 53: 243-282.

Cornelius, S.E. 1986. The sea turtles of Santa Rosa National Park. Fundacion de Parques Nacionales Costa Rica. 64pp.

Crouse, D.T. 1985. The biology and conservation of sea turtles in North Carolina. Ph. D. Diseertation, U. Wisc., Madison.

Crouse, D. T., L. B. Crovder, and H. Casvell. 1987. A stage-based population model for loggerhead sea turtles and implications for conservation. Ecology $68(5): 1412-1423$. 
Deraniyagala, P.E.P. 1939. The tetrapod reptiles of Ceylon. Vol. I. Testudines and Crocodilians. Columbo Mus. Nat. Hist. Ser., Columbo, Sri Lanka. 412 pp.

Dozy, A.M., C.A. Reynolds, J. H. St111, and T.H. Huisman. 1964. Studies on animal hemoglobins. I. Hemoglobins in turtles. J. Exp. Zool. 155: 343-347.

Eckert, K. and C. Luginbuhl. 1988. Death of a giant. Marine Turtle Neviletter 43: 2-3.

Eckert, K. and S. A. Eckert. 1983. Tagging and nesting research of leatherback sea turtles (Dermochelys coriacea) on Sandy Point, St. Croix, USYI, 1983. Final Report to the U.S. Fish and Wildife Service. U. Georgia, Athens.

Eckert, K. L. and S. A. Eckert. 1985. Tagging and nesting research of leatherback sea turtles (Dermochelys coriacea) on Sandy Point, St. Croix, 1985. Ann. Rep. U.S. Fish and Wildl. Serv. MIN548680431 .

Eckert, K. A. and S. A. Eckert. 1988. Pre-reproductive movements of leatherback sea turtles (Dermochelys coriacea) nesting in the Caribbean. Copeia 1988 (2): 400-406.

Eckert, S. A., D.W. Nellis, K. A. Eckert, and G.L. Kooyman. 1986. Diving patterns of tro leatherback turtles (Dermochelys coriacea) during internesting intervals at Sandy Point, St. Croix. Herpet. $42: 381-388$. 
Fabrizio, M. 1986. Stock discrimination in the striped bass, Morone saxitilis. Ph.D. dissertation, University of Rhode Island, Kingston, RI.

Fitter, R.S. 1986. The leathery turtle or luth. Oryx 6: 116-125.

Franklin, I.A. 1980. Evolutionary change in small populations. pp 135-150 In M. Soule and B. Wilcox [eds.] Conservation Biology. Sinauer Assoc. Sunderland, MA.

Frazer, N. B. 1983. Demography and life history evolution of the Atlantic loggerhead sea turtle, Caretta caretta. Ph. D. Dissertation, U. Georgia, Athens.

Frazier, J. 1987. Semantics and the leathery turtle, Dermochelys coriacea. J. Herp. $21(3): 240-242$.

Fretey, J. 1981. Tortues marínes de Guyane. Editions du Leopard d'Or, Paris: 1-136.

Fretey, J. and J. Lescure. 1979. Rapport sur l'etude de la protection des tortues marines en Guyane Francaise. Notes sur le projet de reserve naturelle de Basse Mana a Ministere de la Culture et de l'Environnement. Direction de la Nature, Paris.

Friar, W. 1977. Turtle red blood cell packed volumes, sizes, and numbers. Herpet. 33: 167-190. 
Fritts, T.H., W. Hoffman, and M.A. McGehee. 1983. The distribution and abundance of marine turtles in the Gulf of Mexico and nearby Atlantic vaters. J. Herp. 17: 327-344.

Goff, G.P. and J. Lien, 1988. Leatherback turtles (Dermocehlys coriacea) in cold vaters of Nevfoundland and Labrador. Can. Field. Nat. 102(1): 1-5.

Gorman, G.C. and J. Renzi, Jr. 1979. Genetic distance and heterozygosity estimates in electrophoretic studies: effects of sample size. Copeia 1979(2): 242-249.

Grant, W. and F. Utter. 1984. Biochemical population genetics of the Pacific herring (Clupea pallasi). Can. J. Fish. Aquat. Sci. $41: 856-864$

Grant, W., D. Teel, and T. Kobayashi. 1984. Biochemical population genetics of Pacific halibut (Hippoglossus stenolepis) and comparison vith Atlantic halibut (․․ hippoglossus). Can J. Fish. Aquat. Sci. 38: 1838-1855.

Greer, A.E., J. Lazell, and R. Wright. 1973. Anatomical evidence for a countercurrent heat exchanger in the leatherback turtle (Dermochelys coriacea). Nature 244: 181.

Groombridge, B. 1982. The IUCN amphibia-reptilia red data book. Part 1. Testudines, Crocodylia, Rhyncocephalia. IUCN, Gland, Switzerland : 1-426. 
Hart1, D. 1980. Principles of Population Genetics. Sinauer, Sunderland, MA: $488 \mathrm{pp}$.

Hirth, H. and L. Ogren. 1987. Some aspects of the ecology of leatherback turtle, Dermochelyg coriacea, at Laguna Jalova, Costa Rica. NOAA Tech. Rep. 56.

Ihssen, P.E., H.E. Booke, J. M. Casselmam, J. M. McGlade, N.R. Payne, and F.M. Utter. 1981. Stock identification: materials and methods. Can. J. Fish. Aquat. Sci. 38: 1838-1855.

James, M. 1985. Classification Algorithms. J. Wiley \& Sons, KY.

Kleiman, D.G. 1980. The sociobiology of captive propogation. pp 243262. In M.E. Soule and B. A. Wilcox [eds.], Conservation Biology: An Evolutionary-Ecological Perspective. Sinauer Assoc. Sunderland, MA.

Laist, D.W. 1987. Overview of the biological effects of lost and discarded plastic debris in the marine environment. Mar. Poll. Bull. $18(6): 319-326$.

Lande, R. 1988. Genetics and demography in biological conservation. Science 242: 1455.

Lazell, J.D., Jr. 1980. Nev England vaters: critical habitat for marine turtles. Copeia 1980(2): 290-295.

Leslie, P.H. 1945. On the use of matrices in certain population mathematics. Biometrika 33: 183-212. 
Levins, R. 1968. Evolution in Changing Environments. Princeton University Press: Princeton, NJ.

Levontin, R.C. 1984. Detecting population differences in

quantitative as opposed to gene frequencies. Am. Nat. 123(1): $115-124$

Limpus, C., N. McLachlan, and J. Miller. 1984. Further observations on breeding of Dermochelys coriacea in Australia. Aust. Wildl. Re8. 11: 567-571.

Lynch, C. B. 1977. Inbreeding effects upon animals derived from wild populations of Mus musculus. Evolution 31: 525-537.

McCracken, G.F. and J.W. Bradbury. 1977. Paternity and genetic heterogeneity in the polygynous bat, Phyllostomus hastatus. Science 198: 303-306.

Meffe, G.K. 1986. Conservation genetics and the management of endangered fishes. Proc. Am. Fish. Soc. 11(1): 14- 23.

Meylan, A., P. Meylan, and A. Ruiz. 1985. Mesting of Dermochelys coriacea in Caribbean Panama. J. Herp. 19: 293-297.

Mrosoviky, N. 1987. Leatherback turtle off scale. Nature 327: 286.

o'Brien, S., M. Roelke, L. Marker, A. Newman, C. Winkler, D. Meltzer, L. Colly, J. Evermann, M. Bush, and D. Wildt. 1985. Genetic basis for species vulnerability in the cheetah. Science $227: 1428-1434$. 
Ovens, D.W. and G.J. Ruiz. 1980. Nev methods of obtaining blood and cerebrospinal fluid from marine turtles. Herpet. 36: 17-20.

Parsons, P.A. 1971. Extreme environmental heterosis and genetic loads. Heredity 26: 470-483.

Pritchard, P.C.H. 1971. The leatherback or leathery turtle, Dermochelys coriacea. IUCN Monograph 1: Morges, Svitzerland. 39 pp.

Pritchard, P.C.H. 1976. Post-nesting movements of marine turtles (Cheloniidae and Dermochelyidae) tagged in the Guianas. Copeia 1976: 749-754.

Pritchard, P.C.H. 1980. The conservation of sea turtles: practices and problems. Amer. Zool. 20: 609-617.

Pritchard, P.C.H. 1982. Nesting of the leatherback turtle, Dermochelys coriacea, in Pacific Mexico, vith a nev estimate of the vorld population status. Copeia 1982(4): 741-754.

Rhodin, A.G.J. 1985. Comparative chondro-osseous development and grovth of marine turtles. Copeia 1985: 752-771.

Ross, J. 1982. Historical decline of loggerhead, ridley, and leatherback sea turtles. pp 189-195 In K. Bjorndal [ed.]. Biology and Conservation of Sea Turtles. Smithsonian Institution Press: Washington, D.C. 
Ross, J.P. and J.P. Ottenvalder. 1983. The leatherback turtle, Dermochelys coriacea, nesting in the Dominican Republic. pp 706-713 In A. Rhodin and K. Miyata [eds.]. Advances in Herpetology and Evolutionary Biology. Museum of Comparative Zoology, Cambridge, MA.

Saila, S. and B.K. Martin. 1987. A brief reviev and guide to some multivariate methods for stock identification. Proceedings of the Stock Identification Workshop, Mov 5-7, 1985, Panama City Beach, Fla. NOAA Tech. Mem. NHFS SEFC- 199: 149-174.

Selander R.K. and D.W. Kaufman. 1973. Genic variability and strategies of adaptations in animals. Proc. Nat. Acad. Sci. USA $70(6): 1875-1877$.

Schulz, J. 1975. Sea turtles nesting in Surinam. Zoologische Verhandelingen 143: 1-141.

Shoop, C.R. 1980. Inuit turtle song: leatherback turtles near Baffin Island. Marine Turtle Nevsletter 15: 5-6.

Shoop, C.R. 1987. Sea turtles. In R. Backus and H. Bourne, [eds.]. Georges Bank. MIT Press, Cambridge, MA.

Shoop, C.R., T.L. Doty, and N.E. Bray. 1981. Sea turtles in the region between Cape Hatteras and Mova Scotia in 1979. pp IX: 289 In: A characterization of marine mammals and turtles in the mid- and North Atlantic areas of the U.S. Outer Continental Shelf. Annual Report for 1979, CETAP: Kingston, R. I. 
Smith, H.M. and R.B. Smith. 1979. Synopsis of the herpetofauna of Mexico. Volume VI. John Johnson, North Burlington, VT. 1044 pp.

Smith, M.H., H.O. Hillestad, M.N. Manlove, D. O. Straney, and J.M. Dean. 1977. Management implications of genetic variability in loggerhead and green sea turtles. Proceedings of the 13 th Congress of Game Biologists: $302-312$.

Soule, M.E. 1980. Thresholds for survival: maintaining fitness and evolutionary potential. Pp 151-169 In M.E. Soule and B.A. Wilcox [eds.]. Conservation Biology: An Evolutionary-Ecological Perspective. Sinauer Assoc. Sunderland, MA: 151-169.

Standora, E.A., J.R. Spotila, J.A. Keinath, and C.R. Shoop. 1984. Body temperatures, diving cycles, and movement of a subadult leatherback turtle. Herpet. 40: 169-176.

Stancyck, S.E. 1982. Non-human predators of sea turtles and their control. pp 139-152 In K. A. Bjorndal [ed.] Blology and Conservation of Sea Turtles. Smith. Inst. Press, Wash. D.C.

Thompson, N.B. 1980. Population dynamics of the Atlantic green sea turtle, Chelonia mydas, (Linnaeus) 1758. Ph. D. Dissertation, University of Rhode Island, Kingston, RI.

Thompson, T.J. and C.R. Shoop. 1983. Southeast turtle survey (SETS), pelagic surveys. Final report to NMFS. Aero-marine Surveys Inc. Groton, CT. 76pp. 
Utter, F. 1987. Genetic estimates of stock compositions of 1983 Chinook salmon, Oncorhynchus tshavytscha, harvests off the Washington coast and Columbia River. Fish. Bull. 85(1): 13-23.

Valentine, J. 1977. Genetic strategies of adaptation. pp 78-94 In F. Ayala [ed.]. Molecular Evolution. Sinauer Assoc.: Sunderland, MA.

Vandermeer, J.H. 1975. On the construction of the population projection matrix for a population grouped in unequal stages. Biometrics 31: 239-242.

Whitmore, C.P. and P.H. Dutton. 1985. Infertility, embryonic mortality, and nest site selection in leatherback and green sea turtles in Suriname. Biol. Cons. 34: 251-272.

Wright, S. 1969. Evolution and the Genetics of Populations. Vol. II. U. Chicago Press, Chicago, Ill. 